九州大学学術情報リポジトリ

Kyushu University Institutional Repository

\title{
A SYNOPSIS OF THE BEE GENUS PALAEORHIZA PERKINS(HYMENOPTERA, COLLETIDAE) OF NEW GUINEAPART V. SUBGENUS CNEMIDORHIZA
}

Hirashima, Yoshihiro

https://doi.org/10.5109/2412

出版情報: ESAKIA. 17, pp.1-48，1981-11-30. Entomological Laboratory, Faculty of Agriculture, Kyushu University

バージョン:

権利関係 : 


\title{
A SYNOPSIS OF THE BEE GENUS PALAEORHIZA PERKINS (HYMENOPTERA, COLLETIDAE) OF NEW GUINEA PART V. SUBGENUS CNEMIDORHIZA*
}

\author{
Y OSHIHIRO H IRASHIMA \\ Entomological Laboratory, Faculty of Agriculture, \\ Kyushu University, Fukuoka 812, Japan \\ and \\ Hikosan Biological Laboratory, Faculty of Agriculture \\ Kyushu University, Hikosan, Fukuoka 824-07, Japan
}

\begin{abstract}
A new subgenus Cnemidorhiza is described. It includes 18 species which are divided into 9 species groups. Eleven new species, Palaeorhiza variabilis, simulans, amoena, delicata, parvula, pembertoni, kraussi, cyanea, speciosa, nasalis and convexa, are described. Cnemidorhiza is characterized in having the caudal fimbria and the pygidial plate on the female 6th tergum in addition to the coarsely sculptured hind tibiae. Soil-nesting habits of Palaeorhiza gratiosa Cheesman is discussed laying emphasis on the morphological adaptation which is characteristic to the new subgenus.
\end{abstract}

\section{Cnemidorhiza, new subgenus}

TyPe-SPECies: Prosopiselegans Smith, 1864 (=Palaeorhiza elegantissima (Dalla Torre, 1896))

This is a large subgenus of interesting and very diverse forms which are known from New Guinea, New Britain and Australia. This is characterized by the presence of the caudal fimbria and pygidial plate on the 6th tergum, and the dorsal face of the hind tibia is broadened (at least on the basal portion) and coarsely sculptured or punctate-roughened except for the extreme base only. In addition, the hind femur is not always but often provided with a tuft of short, black, coarse hairs onthe apex. These are very unusual characters for Palaeorhiza, but are seen only in the female.

The caudal fimbria is composed of dense, well appressed, coarse, black or blackish hairs. In elegantissima and its allied species, it is rather short in the

\footnotetext{
* Contribution from the Entomological Laboratory, Faculty of Agriculture, Kyushu University, Fukuoka (Ser. 3, No. 92) and that from the Hikosan Biological Laboratory, Faculty of agriculture, Kyushu University, Hikosan (Ser. 2, No. 46).
} 
middle and does not fully cover the pygidial plate. The pygidial plate is poorly indicated in elegantissima or parallela, but is well developed in Patricia and its allied species or in gratiosa. The dorsobasal area of the hind tibia is broad and very coarsely sculptured in most species such as Patricia, gratiosa, variabilis or wisselmerenensis, but less coarsely sculptured and punctate in elegantissima and pembertoni.

This subgenus includes 18 species which are divided into 9 species groups. These species are very variable in many respects, as follows:

Color: Usually distinctly metallic, but in viridifrons, an Australian species, the head and thorax are dark green and the metasoma is black. The metasoma is variably red in amoena, variabilis, simulans, delicata and parvula (the legs are also red in these species). In addition, the yellow markings are present on the red metasoma in variabilis and an unnamed species from New Britain. In these species having the red-metasoma the head and thorax are also extensively decorated with yellow. The head and thorax are also well decorated with yellow in wisselmerenensis and speciosa, and in some extent, in patricia. In the former two species, the mesoscutum is provided with four yellow stripes, but in Patricia, it has two narrow stripes only. Rarely the mesoscutal yellow stripes disappear in Patricia. In other species, the head and thorax are also decorated with yellow in various ways. For example, the yellow marking is confined to the scutellum, metanotum, tubercle and pre-episternum in viridifrons, but the head is always decorated with five yellow stripes and the pronotum with a yellow band, which is interrupted in the middle in some species except for convexa only. The latter is a large, dark metallic and black-haired species lacking entirely the yellow maculation on the body except for a pair of small evanescent pale spots on the upper portion of the supraclypeal area. Usually the yellow coloration of the male face is more developed than in the female. Thus, the face is entirely yellow in the males of parallela and variabilis and nearly so in pembertoni and simulans. The pattern of the yellow maculation is sometimes reliable to the grouping of the species. For example, in the two species groups, the variabilis and the delicata groups, a pair of yellow markings are present on the propodeal enclosure in addition to the rich markings on the other parts of the head and thorax.

Hairs: Usually the hairs are rather dense but short and not conspicuous on the head and thorax as usual for Palaeorhiza. The hairs are white or silvery in the nasalis and Patricia groups, whitish but darkened hairs present on the vertex and mesoscutum in the variabilis, delicata, wisselmerenensis and elegantissima groups. Hairs are more darker in the viridifrons group, and unusually black, long and dense in the gratiosa and convexa groups. Usually the hairs on the metasoma are whitish basally and blackish apically. The lateral face of propodeum is covered with short dense white (sometimes grey) hairs 
which are especially distinct in wisselmerenensis, simulans and Patricia. In the males of the elegantissima and Patricia groups there are dense white hairs on the underside of thorax. Sometimes three basal terga are provided with lateral fringes of white hairs on the apical margins. These are distinct in simulans, amoena and Patricia. The apical sterna of the male, usually 4 th to 6 th, are covered with more or less dense fuscous hairs, but there is a transverse fringe of long, delicately curved, fuscous hairs on the subapical portions of the 4th and 5th sterna in Patricia and the 3rd to 5th sterna in gratiosa. The apical tuft of black hairs on the hind femur of female is conspicuous in elegantissima and its allied species but obscure in viridifrons.

Mandible: This is usually weakly bidentate in both sexes. In Patricia, however, it is only slightly notched in the female and simple in the male. In parallela, an Australian species, it is subtridentate because of the presence of tooth-like angulation on the upper portion. It is very unusual that in nasalis, the mandible is provided with a triangular process in the middle of the inner margin.

Malar space: This area is distinct, but slightly variable in length, usually about half as long as basal width of mandible.

Clypeus: This area is usually well convex, and the outline of it is arched when the head is seen from the side. The male clypeus is usually flat. In the female convexa (the male is unknown), the clypeus and supraclypeal area are considerably strongly convex. This is unusual for Palaeorhiza. It is very unusual and unique that in the female of nasalis (the male is also unknown) the apical portion of clypeus is reflected and strongly elevated while the basal (upper) portion is flat.

Supraclypeal area: This area provides an interesting feature of modification. In cyanea, gratiosa and kraussi the upper swelling of the supraclypeal area is distinct, highly elevating and sharply defined from the frons. It is also distinctly dilated laterally in viridifrons. In delicata, it is well elevating but not dilated and in other species such as parallela it is more or less low and rounded in outline.

Punctures on the thorax: The punctures on the mesoscutum are variable, extremely dense in elegantissima, variabilis, gratiosa and other species but well separated on the shining ground in cyanea. The punctures on the scutellum are also variable even in the same species group. For example, they are stronger and coarser than those on the mesoscutum in elegantissima, but are weaker in parallela.

Scutellum: This is usually broadly nearly flat or only weakly convex, but in gratiosa and convexa it is slightly depressed in the middle.

Metanotum: This part is more variable than in the scutellum. It is usually slightly convex, but is broad and flat in cyanea and nasalis, and nearly so in 
speciosa, but is distinctly convex in gratiosa and convexa.

Propodeal enclosure : This portion is moderate to large, usually largely dorsal, but in gratiosa it is rather short (as seen from above) and distinctly slanting, and in convexa it is more steep and nearly vertical.

Precoxal carina: This is usually conspicuous and transverse, but l-shaped in elegantissima and pembertoni.

Metasoma: The punctures on the metasoma are very variable, very dense in elegantissima or sparse on two basal terga in convexa. The apical margin of the 2nd tergum is broadly and distinctly produced posteriorly in elegantissima and its allied species, produced but less strongly so in gratiosa or viridifrons, but nearly straight in convexa. The apical impunctate margin of each of basal terga, especially that of the 2nd, is also variable, broad and well indicated in Patricia but linear in elegantissima. It is very interesting that, in the elegantissima species group, the extreme lateroapical corner of the 2nd tergum is acute and nearly right-angled, and this portion is also densely punctate and roughened although the punctures are small.

Male exposed sterna: These are usually unmodified, weakly to distinctly punctate, but in patricia and gratiosa at least the 3rd and 4th sterna are provided with a transverse weak elevation which is glabrous. Subapical fringe of hairs are present at least on the 3rd to 5th sterna in Patricia andgratiosa only.

Nesting habits and morphological adaptation of Cnemidorhiza

Palaeorhiza (Cnemidorhiza) gratiosa Cheesman is a soil-nesting species. In 1969, I dug out a nest of this species on Bulldog Road $(2600 \mathrm{~m}), 35 \mathrm{~km} \mathrm{SE}$ of Wau, Papua New Guinea. Larval cells are found within $10 \mathrm{~cm}$ from the ground surface which was covered by mosses. They were made of transparent cellophane-like material. This habit is characteristic for the bees of the family Colletidae (Michener, 1965, p. 35).

Palaeorhiza (Cnemidorhiza) gratiosa is one of the most striking species whose diagnostic characters for the subgenus are most conspicuous. Namely, it is provided with the well defined pygidial plate which is associated with the dense caudal fimbria on the 6th tergum. Among other bees which nest in the ground, the caudal fimbria is developed on the 5 th tergum and the pygidial plate on the 6th tergum. Andrena, Lasioglossum or Melitta are examples. Wherever they develop, the presence of the caudal fimbria as well as the pygidal plate is thought to be one of the morphological adaptations to nest in the ground. As a matter of fact, it is often observed that a soil nesting bee uses the tip of her abdomen to make the interior wall of the burrow (and probably the larval cells also) solidly. Thus, it is very probable that a similar habit may be s e en in Palaeorhiza (Cnem idorhiza) gratiosa.

In addition, the hind tibia of the female Palaeorhiza (Cnemidorhiza) gratiosa 
is also strikingly modified as described for the subgenus. The coarse structure of the dorso-basal area of the female hind tibia of Palaeorhiza (Cnemidorhiza) gratiosa may be functional to support the body in the burrow. In Andrena, Lasioglossum and Melitta, the female hind tibia is provided with the basitibial plate, however, which is assumed to have the same function while the bees remain in the burrow.

The other species of Cnemidorhiza are supposed also to nest in the ground so far as is judged from their morphological structures which are diagnostic to the subgenus.

Palaeorhiza gressittorum Hirashima, whose soil-nesting habit was disclosed by me in 1975, belongs to a different subgenus which will be discussed in a separate paper.

Key to SPecies groups and SPecies of Cnemidorhiza

FEMALES*

1. Medium-sized to large, robust species; head and thorax metallic (usually bluegreen) with rich yellow markings (mesoscutum with four yellow stripes and propodeal enclosure with a pair of yellow markings) ; at least two basal terga red; metasoma with or without yellow markings; legs red, with yellow markings often extensive; tuft of dark hairs on apex of hind tibia not always distinct;

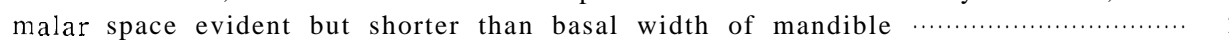

- Head and thorax with fewer yellow markings or yellow marking absent; usualy no yellow marking on propodeal enclosure

2. Head and thorax with punctures strong, usually dense; punctures on scutellum usually slightly roughened and slightly larger than those on mesoscutum ......

The species group of variabilis....... 3

- Head and thorax with punctures very small and very dense; punctures on scu-

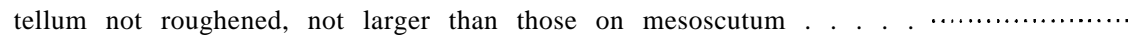

.The species group of delicata

3. Rather large species; punctures on thorax not specially strong, but those on mesoscutum and scutellum very dense; pre- and meso-episterna shining, with yellow marking constricted on upper portion only except for small evanescent yellow markings near lower end of pre-episternal groove; propodeum without yellow marking except for enclosure ; five stripes on head, band on pronotum, four stripes on mesoscutum (lateral ones shorter), mark on axilla, lateral stripe on scutellum, a pair of transverse marks on metanotum, a pair of longitudinal marks on propodeal enclosure, large mark on tubercle, interrupted transverse mark on upper portion of side of thorax pale yellow; about apical half of metasoma slightly darkened, not blackish; white lateral hair fringes on three basal terga more or less evident; apex of hind tibia almost without

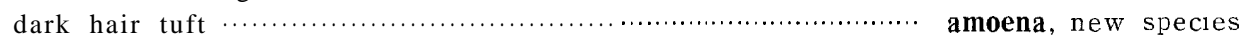

- Medium-sized or rather large species; punctures on thorax strong and very dense; pre- and meso-episterna with extensive yellow markings even on lower portions ; lateral face of propodeum with large (in variabilis) or small and eva-

4. Head and thorax with extensive pale yellow markings even on propodeum;

* Females of kraussi and speciosa are unknown. 
three basal terga red with large yellow markings; white hair fringe absent

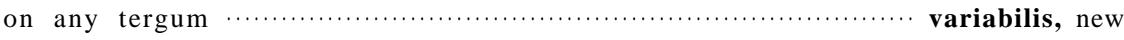

- Head and thorax with extensive pale yellow markings except for lateral face of propodeum; three basal terga red, without yellow marking; white lateral hair fringes on three basal terga rather distinct; punctures on mesoscutum and scutellum very strong, slightly coarser than in variabilis.... simulans, new species

5. Rather large species from New Ireland; head and thorax steel-blue, with clypeus blackish or piceous and shining; mark on labrum, five stripes on head, band on pronotum, four stripes on mesoscutum, mark on axilla, lateral stripe on scutellum, a pair of transverse marks on metanotum, a pair of longitudinal marks on propodeal enclosure, large mark on tubercle. interrupted transverse mark on side of thorax below tegula, not clear-cut mark on side of propodeum behind lemon yellow ; metasoma broadly red, apex only darkened; mesoscuturn and scutellum with punctures very small and very dense; metasomal

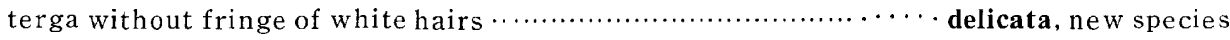

- Large species from New Britain; head and thorax with more extensive pale yellow markings (side of thorax with extensive pale yellow marks even on lower portion); at least two basal terga red, with broad yellow bands

Palaeorhiza sp.

6. Rather small species; head and thorax blue-green with rather rich yellow markings as follows: five stripes on head, band on pronotum, four stripes on mesoscutum, mark on axilla, lateral stripe on scutellum, band on metanotum, mark on tubercle, and interrupted transverse band on upper portion of side of thorax; legs red or largely so ; two basal terga red in parvula, new species $\ldots .$. The species group of wisselmerenensis $\ldots . . . .7$

- Larger and usually more robust species; head and thorax with yellow marking variable (absent in robusta, new species); mesoscutum without yellow marking except for Patricia Cheesman which is a large blue species $\ldots \ldots \ldots \ldots \ldots \ldots \ldots \ldots \ldots \ldots \ldots{ }^{*} .8$

7. Legs red except coxae; metasoma not red, with rather distinct metallic reflection (blue and purple) even on two basal terga; median and basal portions of 2nd tergum nearly smooth with sparse and weak punctures

wisselmerenensis Hirashima

- Legs darkened basally on fore and middle pairs; two basal terga red (2nd tergum often darkened and then metallic on median portion); 2 nd tergum slightly more roughened (although microscopical), with very small and closer

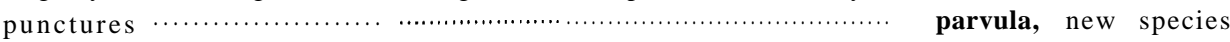

8. Medium-sized, robust, green or blue-green species; mesoscutum very densely, rather strongly to strongly punctate; head and thorax with more or less rich yellow marking; metanotum at least with a median yellow mark; 2nd tergum with latero-apical corner acute and nearly right-angled (this is unusual for Palaeorhiza); this portion also densely and minutely pun\&ate-roughened . ........ ......... The species group of elegantissima $\cdots \cdots \cdots 9$

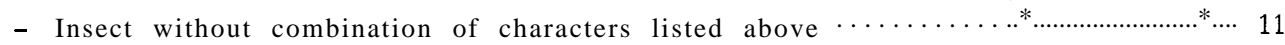

9. Green species from Australia; head and thorax with yellow markings as follows: five stripes on head, band on pronotum, mark on axilla (sometimes absent), large marks on scutellum and metanotum covering nearly full spaces of respective areas, mark on tegula, large mark on tubercle, and mark of variable size on upper portion of pre-episternum (sometimes absent) ; legs with a few yellow marks; hind femur with apical tuft of fuscous hairs distinct

parallela Cockerell

- Green or blue-green species from New Guinea; scutellum with a pair of lateral 
yellow marks; yellow mark on metanotum reduced to a median mark; hind

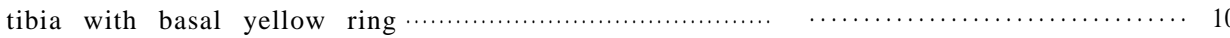

10. Length about $8 \mathrm{~mm}$; clypeus principally purple; five stripes on head, band on pronotum, lateral stripes on mesoscutum, mark on axilla, lateral stripe on scutellum (not reaching apical margin), median mark on metanotum, spot on tegula, mark on tubercle, and large mark on upper portion of pre-episternum yellow; punctures on mesoscutum strong and exceedingly close, those on scutellum stronger than those on mesoscutum; metanotum also with rather strong punctures; apical tuft of black hairs on hind femur distinct; femora and tibiae fulvous or red (except for fore femora), coxae, trochanters and tarsi brownish; metasoma dark green with strong purple tint, especially on median portions of two basal terga; lateral white hair fringes on three basal terga more

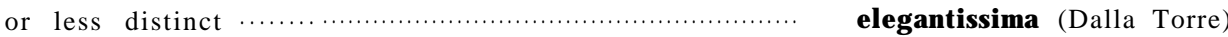

- Similar to the preceding species, but yellow marking on mesoscutum reduced to small mark on transscutal suture, and that on scutellum also much smaller (rarely absent); legs not reddened; clypeus with green tint; metasoma with

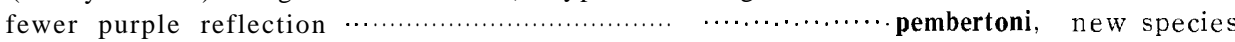

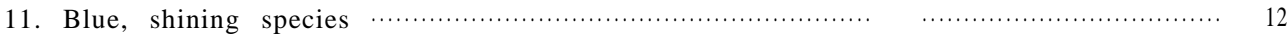

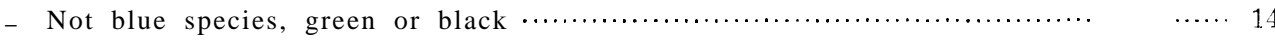

12. Rather large species; clypeus strongly reflected and elevated on apical portion ; mandible with triangular process in middle of inner margin; head with five, pale yellow (slightly bluish), broad stripes; interrupted band on pronotum and a small spot on transscutal suture of scutellum also pale yellow; hairs white or silvery, no dark hairs on vertex and mesoscutum .... nasalis, new species

- Clypeus normal; mandible without tubercle on inner side ; propodeal enclosure large, shining; head and thorax with yellow or pale markings not extensive, but head always with five narrow stripes; hairs on thorax primarily white; short white hairs on lateral face of propodeum usually distinct; metasoma sometimes partly reddened....................... The species group of patricia

13. Slightly less than $10 \mathrm{~mm}$; mesoscutum and scutellum very densely, strongly, nearly rugosely punctate; mesoscutum with short fuscous hairs predominant but not conspicuous ; thorax with yellow or pale markings as follows: narrow band on pronotum (sometimes interrupted in middle), two narrow stripes on mesoscutum, triangular mark on axilla, lateral narrow stripes on scutellum, a pair of small marks on metanotum, spot on tubercle, and three small marks on upper portion of side of thorax (rarely a pair of small spots present on propodeal enclosure) ; apical tuft of fuscous hairs on hind femur not distinct ; three basal terga with lateral fringes of short, dense, white hairs distinct ......

patricia Cheesman

- About as large as patricia; head and thorax blue, shining, metasoma much darker, blue with purple tint, apical portions of at least three basal terga variably reddened; thorax with interrupted yellow band on pronotum, and no other pale mark; mesoscutum shining, with more or less dense, not strong punctures, without dark hair ; metanotum flat, nearly smooth, shining, with sparse, microscopical punctures ; metasomal terga without fringe of white hairs; unlike Patricia, upper portion of supraclypeal area well elevated, dilated and distinctly separated from frons

cyanea, new species

14. Large (about $10 \mathrm{~mm}$ ), rather robust, dark green species from Australia; thorax with unique yellow markings or portions as follows: scutellum, metanotum, mark on tubercle, and very large mark on pre-episternum behind tubercle; metasoma nearly black with weak metallic reflection; upper half of supraclypeal 
area well dilated laterally, with distinct median sulcus extending to mid

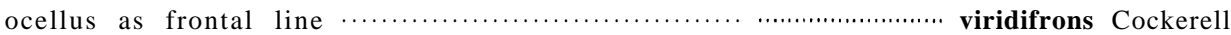
Larger and more robust species from New Guinea; head and thorax with rich

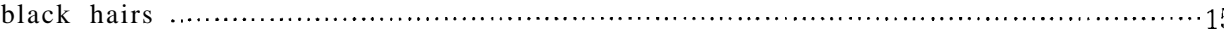

Blue-green species; head and thorax with yellow markings as follows: five stripes on head, band on pronotum, linear band on scutellum next to metanoturn, broad band on metanotum, mark on tegula, and large mark on tubercle; metasoma darker than in thorax, but still with distinct metallic tint; supraclypeal area between antennae well elevated, dilated laterally with sharp edges ; wings distinctly darkened ; very conspicuous species ........... gratiosa Cheesman Dark blue-green species (with purple tint), entirely without yellow marking (but with a pair of evanescent small yellow spots on upper portion of supraclypeal area); clypeus and supraclypeal area strongly convex; frons lateral to frontal line also convex (as continuation of supraclypeal area) ; mesoscutum microscopically tessellate with strong, not specially dense punctures; scutellum slightly depressed medially, rather distinctly elevated laterally; metanotum distinctly convex medially; propodeum rather short, therefore propodeal enclosure not dorsal but steep and subvertical (this is rather unusual for Palaeorhiza): unique species................................................. convexa, new species

\section{ALES*}

Head and thorax metallic with extensive yellow markings; yellow markings present even on propodeal enclosure; metasoma and legs largely red $\ldots \ldots \ldots \ldots \ldots \ldots \ldots \ldots \ldots \ldots$ Propodeal enclosure without yellow marking; when occasionally present, blue species

Rather large species; punctures on thorax very small and very dense; wings yellow with distal portions darkened ; a species from New Britain ................

Palaeorhiza sp.

Medium-sized, robust species; punctures on thorax strong; wings not yellow; species from New Guinea

Malar space yellow; propodeum broadly yellow on lateral face; at least three basal terga red with broad yellow markings; no tergal hair fringe .................

variabilis, new species

Malar space not yellow; lateral face of propodeum without yellow marking, with dense covering of grey hairs; basal two or three terga red, without yellow marking, with white lateral tergal hair fringes (those on 3rd obscure) ….........

simulans, new species

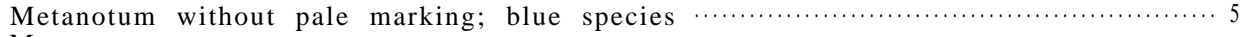

Metanotum with yellow or pale marking.

Mesoscutum strongly and densely punctate; head and thorax with pale markings as follows: five stripes on head, band on pronotum interrupted in the middle, two narrow stripes on mesoscutum (rarely evanescent), triangular mark on axilla, small lateral stripes on scutellum (rarely absent), small lateral marks on metanotum (rarely absent), mark on tubercle, and three marks on side of thorax below wing bases; short white dense hairs on lateral face of propodeum distinct; white fringes of hairs present on three basal terga ; 4 th and 5 th sterna each with a curled fringe of long fuscous hairs subapically .....

* Males of amoena, delicata, elegantissima,nasalis, viridifrons and convexa are unknown. 
- Mesoscutum more or less strongly, somewhat sparsely punctate; head with five pale yellow stripes, the median facial stripe not beyond supraclypeal area (thus no stripe on frons); thorax without yellow marking except for band on pronotum (sometimes small pale yellow markings present on postero-lateral portion of mesoscutum, axilla, tubercle, and upper portion of pre-episternum); no tergal hair fringe; 4th to 6th sterna with fuscous hairs not arranged in a

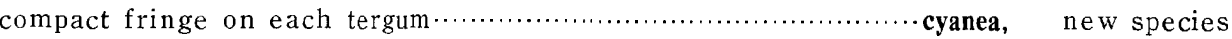

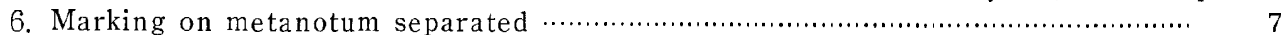

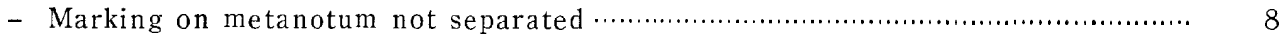

7. Large, blue species ; malar space long; scape long, slender, without yellow stripe (see also couplet 5) …........................................patricia Cheesman

- Smaller, greenish blue species; head and thorax with yellow markings well developed, as follows: basal stripe on mandible, labrum, clypeus except lateral margins, stripe on supraclypeal area extending to frons, long and broad stripe on paraocular area, stripe on genal area along eye margin, stripe on scape, band on pronotum, four stripes on mesoscutum, axilla, lateral stripe on scutellum, a pair of large transverse marks on metanotum, tubercle, and three close marks on side of thorax below wing bases; tergal hair fringes sparse ; no special fringe of hairs on apical sterna ....................... speciosa, new species

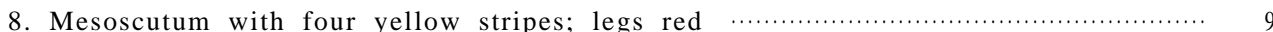

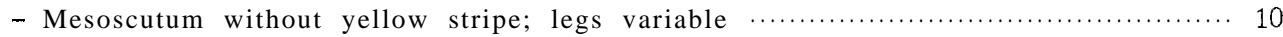

9. Rather small species; head and thorax dark metallic blue (or blue-green) with basal stripe on mandible, labrum, five stripes on head, stripe on scape, band on pronotum, four stripes on mesoscutum, axilla, lateral stripe on scutellum, band on metanotum, tubercle, three transverse marks on side of thorax below wing bases pale yellow; metasoma purple with blue tint … wisselmerenensis Hirashima

- Similar to the preceding species, but metasoma red basally …… parvula, new species

10. Large, blue-green species, but head and thorax often with strong purple tint; head and thorax with rich black or blackish hairs; yellow marks or portions of head and thorax as follows: three stripes on face, narrow stripe on genal area along eye margin, anterior stripe on scape, band on pronotum, posterior mark on scutellum next to metanotum, metanotum, tubercle, and mark on tegula; legs red except basal portions; 3rd to 5 th sterna each with a fringe of

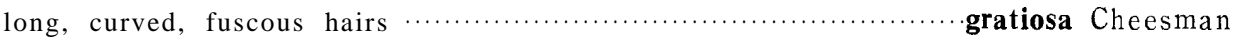

- Medium-sized to more or less small species; head and thorax without blackish hairs, not hairy; extreme latero-apical corner of 2 nd tergum nearly rightangled; no hair fringe on apical sterna; primarily green species

11. Species from Australia; head with rich pale yellow markings including scape ; thorax with band on pronotum, mark on axilla (rarely absent), scutellum except basal margin, metanotum, tubercle, mark on pre-episternum behind tubercle (variable in size, rarely absent), and small mark on tegula orange yellow; metasomal terga well punctate

parallela Cockerell

- Species from New Guinea; yellow mark on scutellum reduced to lateral small mark or spots; rarely small yellow mark present on transscutal suture of mesoscutum; yellow mark on metanotum reduced to median mark ; scape without yellow stripe

12. Thorax strongly and densely punctate; carina on lower portion of mesepisternum in front of mid coxa very strong, I-shaped; green species …...........

pembertoni, new species

- Thorax more or less well punctate but punctures not strong; precoxal carina strong, but transverse ; metasoma weakly punctate; impunctate apical margin 
of 2nd tergum well marked, broad; blue-green species; wings distinctly brown-

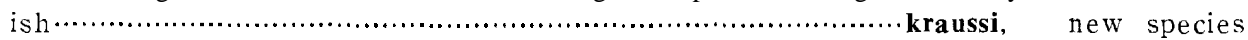

\section{The species group of variabilis}

This is composed of three new species, variabilis, simulans and amoena, from $\mathrm{New}$ Guinea. This is a group of medium-sized to large, robust species which are metallic (head and thorax) and red (metasoma and legs) with extensive yellow markings on the head and thorax and, in variabilis, further on the metasoma. It is verystriking to this species group that the propodeal enclosure is always provided with a pair of large yellow markings.

The condition of important subgeneric characters of this group is as follows : Caudal fimbria well developed with dense, well appressed, fuscous or nearly black hairs; pygidial plate well carinate laterally on apical portion; hind tibia thick, dorso-basal face well marked, very coarsely sculptured except for extreme base only; apical tuft of short dense hairs not distinct in amoena only.

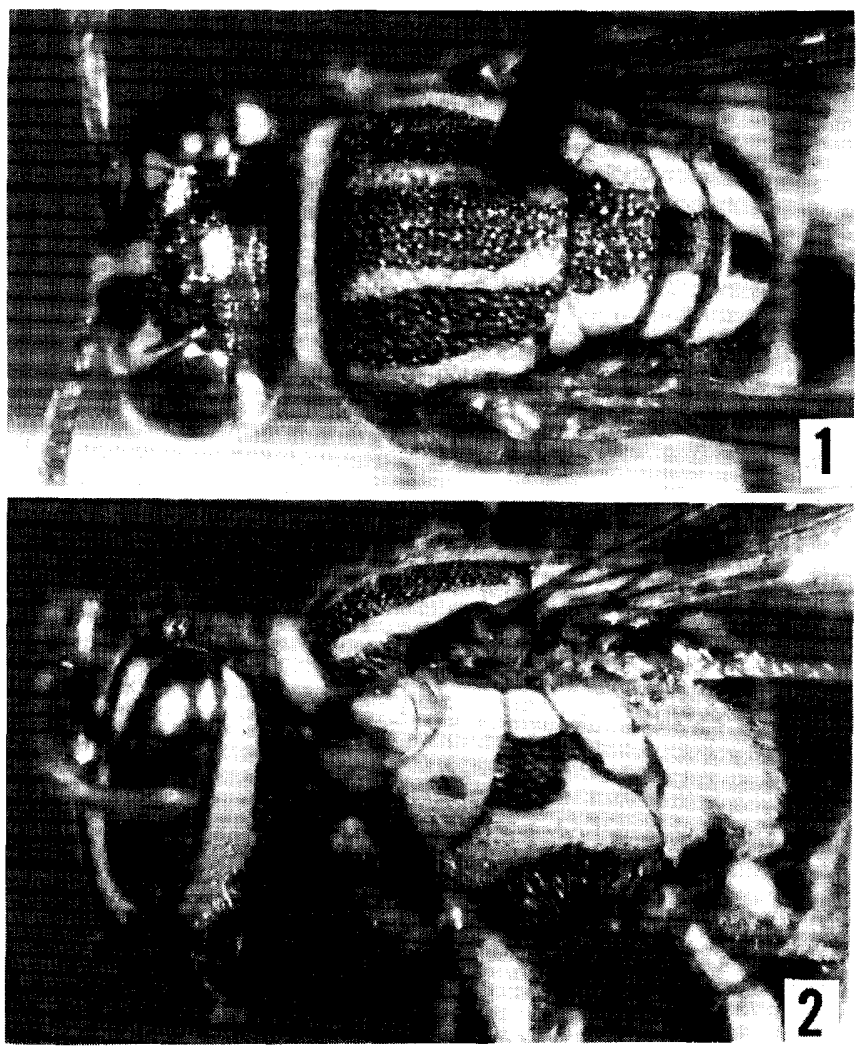

Figs. 1 and 2 Palaeorhiza (Cnemidorhiza) variabilis, new species, female. 1 : Dorsal view of the head and thorax. 2: Lateral view of the same. 


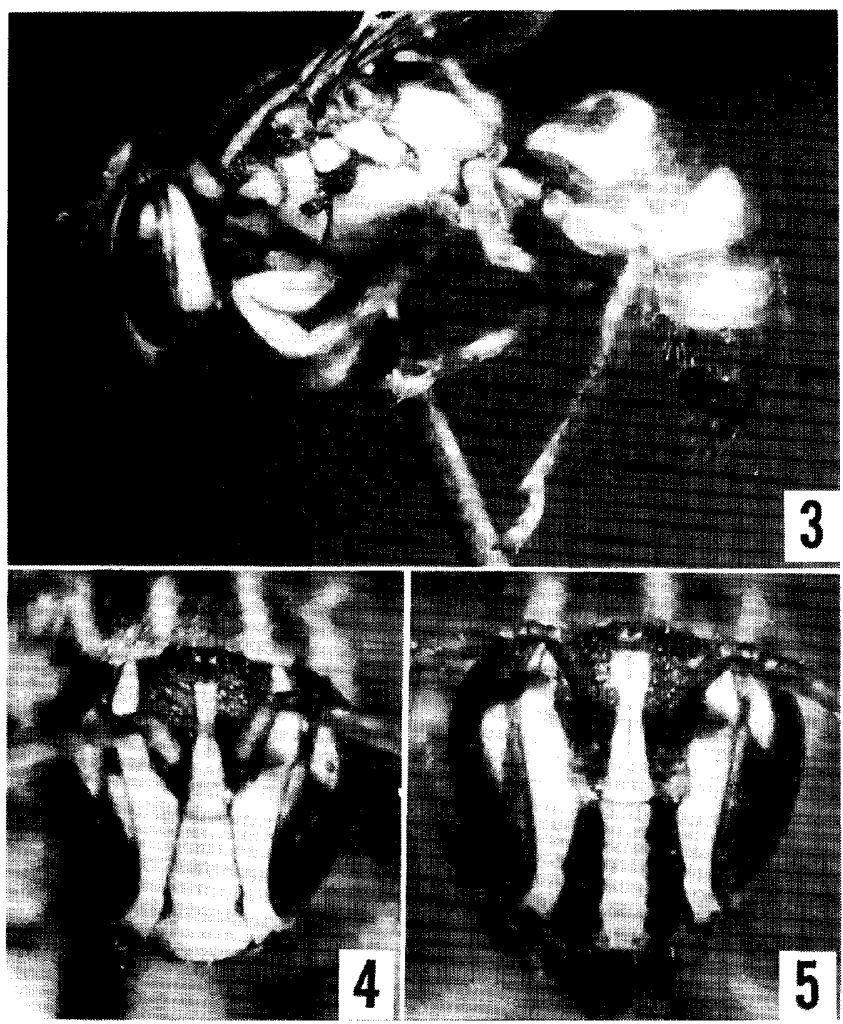

Figs. 3-5. Palaeorhiza (Cnemidorhiza) variabilis, new species. 3: Lateral view of the male. 4: Male head. 5: Female head.

Further characters of importance of this group are as follows: Lower portion of mesepisternum in front of precoxal carina considerably coarsely sculptured with strong rugae and puncture-like excavations; mesoscutum and scutellum very densely punctate, punctures very strong in variabilis and simulans; punctures on scutellum coarser than those on mesoscutum ; punctures on metasoma variable, as stated below. Male: malar space only slightly longer than in female; flagellum long, with 3rd segment longer than broad but not longer than two basal segments together; venter of metasoma shining, strongly punctate, without special modification and without special fringe of hairs.

This is further divided into two species subgroups, based on the female, as follows :

(A) The species subgroup of variabilis: Two species, variabilis and simulans. Mandible rather slender, nearly straight with narrow apical blade, weakly bidentate ; preoccipital carina reflected ; punctures on mesoscutum and scutellum very strong; side of thorax with extensive yellow markings; punctures on two basal terga rather sparse; punctures on 3rd dense, variable in size, but 
much coarser than those on 2nd; apical tuft of brown hairs on hind femur distinct; tergal hair fringe present (in simulans) or absent (in variabilis); yellow marking of metasoma present (in variabilis) or absent (in simulans).

(B) Species subgroup of amoena: One species only. Mandible more or less broad, well curved, with broad apical blade which is only weakly notched about in the middle; preoccipital carina not reflected; punctures on mesoscuturn and scutellum moderate in size or rather small for the size of insect; side of thorax with yellow marking defined to upper portion only except for evanescent small mark near end of pre-episternal groove; punctures on two basal terga very close and small; punctures on 3rd very close, not much roughened as in the variabilis subgroup; tergal hair fringes present; metasoma without yellow marking.

(A) The spectes subgroup of variabilis

\section{(1) Palaeorhiza (Cnemidorhiza) variabilis, new species}

The description of this new species is based on 5 female and 5 male specimens from Papua New Guinea. This is a medium-sized, robust, amazingly colored species. The very strong punctation on the mesoscutum and scutellum is also one of the distinctive characters of this species.

Female: Length about $8 \mathrm{~mm}$.

Relative head measurements : length, 32 ; width, slightly over 34 ; upper interocular distance, 17; width of face, 21.5 ; lower interocular distance, 17 ; eye length, slightly less than 26; clypeal length, 14 (length of clypeus below level of lower margins of eyes, about 5). Inner eye margins slightly converging below; malar space not long, less than one-half as long as basal width of mandible; clypeus well convex; supraclypeal area more convex in the middle ; upper swelling of supraclypeal area rather broad, not dilated, gradually reducing its height toward above, upper end obscure and not sharply defined from frons ; clypeo-ocular distance longer than malar space ; ocelli rather large, posterior ocellus slightly larger than mid ocellus, ratio of width of posterior ocellus to postocellar distance to ocellocular distance to ocelloccipital distance as $7: 8: 11: 12$; face below antennae weakly and sparsely punctate ; frons strongly punctate ; area behind ocelli strongly slanting posteriorly, somewhat distinctly punctate. Collar of pronotum rather broad, rounded laterally; mesoscutum very strongly and densely rugoso-punctate as mentioned above, shining; scutellum flat, more coarsely, still densely punctate; propodeal enclosure well convex, nearly smooth, shining; pre- and meso-episterna with rather dense punctures much weaker than those on mesoscutum. Wings slightly brownish subhyaline ; stigma and 2nd submarginal cell moderate in size. Metasoma long oval, well convex; 2nd tergum well convex in the middle, constricted basally and slightly so apically; two basal terga smooth, strongly shining, with distinct 
punctures not dense, irregular in size and distribution; 3rd tergum microscopically reticulate, punctures small basally, becoming considerably larger toward apex; punctures on medio-subapical portion of 3rd much coarser than those on corresponding portion of 2 nd; apical impunctate margin of 2 nd tergum broad, well marked.

Head and thorax distinctly metallic, bronze, shining, with yellow markings or portions as follows : mandible except apical half, labrum, three broad and long stripes on face, anterior portion of malar space, genal area except behind, collar of pronotum, four broad stripes on mesocutum, axilla, lateral portion of scutellum, a pair of transverse mark on metanotum, a pair of large marks on propodeal enclosure, large mark on side of pronotum, tubercle, nearly all space of pre-episternum, nearly all space of mesepisternum except bronze marks on upper and lower portions, nearly full space of metepisternum and nearly full space of side of propodeum; malar space often all yellow; posterior face of propodeum often with yellow marks (variable in size); the median stripe of face with upper end almost reaching mid ocellus; legs red with extensive yellow markings basally; at least three basal terga and four basal sterna red, the rest of metasoma blackish with metallic (usually purple) shade; three basal terga with large yellow markings variable in shape and size.

Not hairy; hairs mostly white but those on vertex and mesoscutum brownish; side of propodeum with covering of hairs short, white; not specially distinct; metasoma without tergal hair fringe, with hairs on apical portion black.

Male: Smaller and slenderer than female.

Relative head measurements : length, 31; width, 31.5; upper interocular distance, 16; width of face, 19; lower interocular distance, a little less than 13; eye length, 25 ; clypeal length, 13.5 (length of clypeus below level of lower margins of eyes, about 4.5). Mandible nearly simple; malar space about half as long as basal width of mandible, much shorter than clypeo-ocular distance; clypeus rather elongate, broadly flat with a median longitudinal weak elevation; upper portion of supraclypeal area slightly more convex than in female, more abrupt; ratio of width of posterior ocellus to postocellar distance to ocellocular distance to ocelloccipital distance as $7: 9: 9.5: 12$. Scape rather short, not swollen; flagellum long, with two basal segments broader than long. Metasoma not specially elongate ; 2nd tergum more convex transversely than in female; three basal terga more strongly punctate than in female, especially punctures on 3rd large and conspicuous; 7th tergum with latero. apical projection not large, triangular. Coloration similar to female, but mandible red only apically and scape broadly yellow in front.

Type materias : Holotype female (BISHOP 12307) and 3 males, Wau, $1200 \mathrm{~m}$, Papua New Guinea, 21. VII. 1969 (Y. Hirashima) ; 4 paratopotype females and 
2 paratopotype males (Gressitt, Sedlacek).

Distribution : Papua New Guinea.

Type Depository: B. P. Bishop Museum, Honolulu.

\section{(2) Palaeorhiaa (Cnemidorhiza) simulans, new species}

The description of this new species is based on 1 female and 3 male specimens from Papua New Guinea. This is about as large as variabilis and superficially similar to it, but is very distinct, and separable as follows:

Female and male: Mesoscutum and scutellum more strongly and coarsely punctate; propodeal enclosure with median portion longitudinally slightly depressed; malar space not yellow; pronotum without yellow marking at side ; markings on pre- and meso-episterna less extensive; posterior and lateral faces of propodeum without yellow marking except for small evanescent pale markings on posterior portion of the latter in female; metasoma without marking; three basal terga with lateral fringes of slightly greyish white hairs (fringe of male 3rd tergum sparse).

This is further distinct as follows:

Female: Frons, mesoscutum, scutellum, metanotum and propodeal enclosure slightly more reticulate, therefore less shining than in variabilis, nearly dull; metasoma with three basal segments red.

Male: Clypeus not entirely yellow (entirely yellow in variabilis), piceous laterally ; tibiae and tarsi of middle and hind pairs with brownish patches; coloration of metasoma variable but at least two basal terga red; 3rd and following terga purple ; venter of metasoma red basally, purple apically, but variable.

TyPe Material: Holotype female (BISHOP 12308) and 3 males, Baiyer River, 1100 m, Western Highland, Papua New Guinea, 1-5. IX. 1969, on Rubus flowers (Y. Hirashima).

Distribution : Papua New Guinea.

Type Depository: B. P. Bishop Museum, Honolulu.

(B) The SPECIES SUbGRoup of amoena

\section{(3) Palaeorhiza (Cnemidorhixa) amoena, new species}

The description of this new species is based on a single female specimen from New Guinea. The much weaker punctation on the mesoscutum and the 2nd and 3rd terga easily separates this from the two preceding species. The mode of the punctation of the metasomal terga is also different from that of variabilis and simulans, as mentioned above.

Female: Slightly larger and robuster than simulans.

Relative head measurements : length, 36.5; width, 38.5; upper interocular 


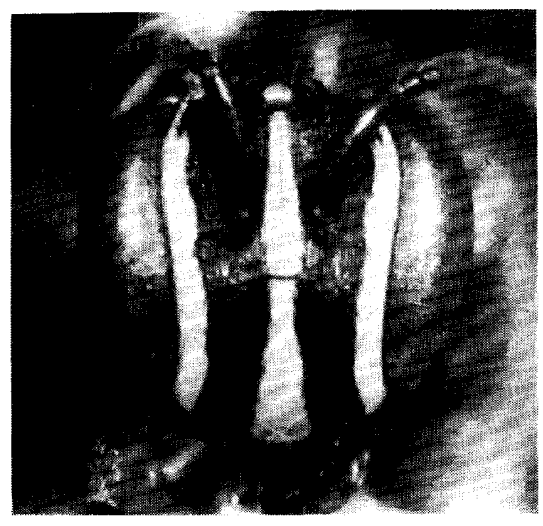

Fig. 6. Palaeorhiza (Cnemidorhiza) a:moena. new species. Fernale head.

distance, about 19; width of face, 23.5; lower interocular distance, 20; eye length, 29; clypeal length, slightly over 15 (length of clypeus below level of lower margins of eyes, about 6). Inner eye margins only slightly converging below; malar space narrowed anteriorly, about half as long as basal width of mandible in the middle; clypeo-ocular distance broader than malar space; clypeus and supraclypeal area well convex, its outline arcuate as seen in profile; upper portion of supraclypeal area not dilated laterally, not highly convex (less convex than in variabilis and simulans), gently reducing its height toward above and gently merged in frons; ocelli more or less large, posterior ocelli rather broadly separated each other; ratio of width of posterior ocellus to postocellar distance to ocellocular distance to ocelloccipital distance as 7.5 : 10 : 11 : 13; space behind ocelli strongly slanting posteriorly. Clypeus weakly longitudinally striate-punctate; paraocular area below antennae more weakly punctate; frons more weakly punctate than in variabilis. Mesoscutum very densely and more or less strongly punctate, punctures much weaker than in variabilis, much stronger than in delicata, which represents another species group; scutellum flat, slightly more coarsely punctate than in mesoscutum; metanotum with median portion densely and weakly punctate on microscopically reticulate and nearly dull ground, lateral portion sparsely punctate on shining and colored ground; propodeal enclosure well convex, largely dorsal, surface microscopically reticulate, rather shining; pre-episternum very densely punctate; metepisternum with punctures a little sparser than those on preepisternum and mesoscutum, slightly irregular in size and a little weaker than those on mesoscutum. Hind tibia with dorso-basal face broad, very coarsely sculptured except for extreme base only; apical tuft of dark hairs on hind femur not distinct. Firsttergumrather densely, weakly punctate on microscopically lineolate and shining ground, apical impunctate margin not sharply defined, rather broad in middle; 2nd tergum not specially convex medially, constricted basally, slightly depressed apically, rather densely and weakly 
punctate, punctures even close on median portion of tergum and slightly larger than those on 1st; apical impunctate margin of 2nd tergum not clearly marked, transversely microscopically lineolate, rather broad in middle; 3rd tergum with weak and very dense punctures on basal portion becoming slightly larger and coarser toward apical portion; punctures on 1st and 2nd terga much weaker and much closer than in variabilis, those on 3rd also very much weaker than in the latter species.

Head and thorax metallic, blue with slight green shade, and with slight purple tint; mandible, clypeus and its neighbouring areas, genal area and scape piceous ; five broad and long stripes on head, band on pronotum, four broad stripes on mesoscutum (lateral ones shorter), axilla, broad lateral stripe of scutellum, transverse mark on side of metanotum, a pair of large marks on propodeal enclosure, large mark on tubercle, three transverse marks on side of thorax below wing bases, and evanescent small marks near end of pre-episternal suture yellow (marks on propodeum and side of thorax nearly ivory). Wings subhyaline, distal portions slightly darkened; veins and stigma brown. Coxae and trochanters dark with metallic shade; femora and tibiae fulvous or more yellowish, with not extensive yellow markings; tarsi darkened. Two basal segments of metasoma fulvous or more yellowish, without yellow marking; 3rd tergum fulvous and dark (dark portion with purple shade) ; 4th and following terga dark as in dark portion of 3rd.

Hairs not conspicuous, whitish on head and thorax; hairs on vertex and mesoscutum slightly brownish; covering of short hairs on lateral face of propodeum rather dense; white lateral tergal hair fringes on three basal terga rather distinct; hairs on apical portion of metasoma fuscous.

Type materias: Holotype female, Mt. Lamington, N. E. Papua, 1300 to 1500 feet, C. T. McNamara (no date).

Distribution: Papua New Guinea.

TYPE DEPOSITORY: University of Kansas, Lawrence.

\section{The species group of delicata}

This is composed of two species, delicata, new species, from New Ireland and another undescribed species from New Britain. This is very close to the variabilis species group but differs as follows: lower portion of mesepisternum in front of precoxal carina impunctate, only slightly roughened ; mesoscutum and scutellum with punctures very small (although very dense) and punctures on the latter scarcely coarser than those on mesoscutum; 3rd tergum with punctures nearly obsolete (but with an indication of very weak and dense punctures); and wings yellow.

The important subgeneric characters of this group are as follows: Caudal fimbria well developed with dense, appressed, coarse, fuscous hairs; pygidial plate well defined laterally by distinct carina; hind tibia with dorso-basal face 
broad, coarsely sculptured except for extreme base only; apical tuft of dense short hairs well developed, but pale in color in delicata.

Further characters of importance of this group are as follows: Ground coloration and mode of yellow markings similar to the variabilis species group; yellow markings on side of thorax variable, extensive in a species from $\mathrm{New}$ Britain, much less developed in delicata; metasomal terga with or without yellow markings; tergal hair fringe absent.

\section{(4) Palaeorhiza (Cnemidorhiza) delicata, new species}

This species is known from New Ireland. Unfortunately the description of this species is based on the holotype female only. This is unique in having the very dense and minute punctures on the mesoscutum and scutellum, which are dull as in the remaining portions of the thorax, although distinctly metallic. This is also easily separable from its relative, an unnamed species from New Britain, by the absence of yellow marking on the lower portion of the thorax and on the metasomal terga.

Female: Length about $8.5 \mathrm{~mm}$.

Relative head measurements : length, 34; width, 36 ; upper interocular distance, 18 ; width of face, 23; lower interocular distance, 18; eye length, 28; clypeal length, 14. Mandible weakly bidentate ; malar space about half as long as basal width of mandible, shorter than clypeo-ocular distance; inner eye margins slightly converging below ; clypeus and supraclypeal area well convex; upper portion of the latter slightly dilated laterally, not highly convex, gently reducing its height toward above, upper limit indistinct; ocelli moderate in size; ratio of width of posterior ocellus to postocellar distance to ocellocular distance to ocelloccipital distance about as $7: 8.5: 11: 13$. Lower half of face below antennae nearly smooth, shining ; frons dull, with very weak and close punctures, Mesoscutum and scutellum dull, minutely and very densely punctate, punctures on the latter not coarser than those on the former; metanoturn similar to scutellum but punctures more minute; propodeal enclosure with enamel-like lustre, microscopically lineolate; pre- and meso-episterna also nearly dull with enamel-like lustre, punctures as close as but slightly more minute than those on mesoscutum. Metasoma rather broad with 2nd tergum well constricted basally and apically; two basal terga with minute and very close punctures, punctures dense even on median portion of 2nd tergum; depressed apical margin of 2nd tergum broadly impunctate.

Head and thorax metallic, blue with slight purple shade; mandible, malar space, apical margin of clypeus and antennae beneath reddened; clypeus nearly piceous; lateral face of pronotum and posterior face of propodeum (and its adjacent portion) reddened with purple tint, especially on the latter; labrum, five stripes on head, band on pronotum, four stripes on mesoscutum, axilla, 
lateral stripe of scutellum, lateral transverse mark on metanotum, a pair of large marks on propodeal enclosure, tubercle, three transverse marks on side of thorax below wing bases (the last one on metepisternum divided into two parts), longitudinal but not clearly defined mark on side of propodeum posteriorly, and evanescent small marks on side of pronotum and near end of preepisternal suture lemon yellow; tegula ferruginous. Wings yellow with yellow hairs, apical margins narrowly darkened ; veins and stigma pale ferruginous (subcosta brownish). Legs red (ferruginous), variegated with yellow; coxae pale reddish brown; tarsi slightly darkened. Metasoma red (ferruginous), apical portion only (about 2 segments) slightly darkened.

Hairs not conspicuous ; hairs on vertex and mesoscutum slightly brownish ; covering of short grey dense hairs on metepisternum and side of propodeum distinct; legs with hairs yellowish ; metasoma with hairs ferruginous basally, fuscous apically (hairs on 4th tergum mostly ferruginous with sparse coarse fuscous hairs intermixed).

Type material: Holotype female (BISHOP 12309), Lelet Plateau, Schleinitz Mts., New Ireland, Oct. 1959 (W. W. Brandt).

Distribution: New Ireland.

TyPe depository: B. P. Bishop Museum, Honolulu.

(5) Palaeorhiza (Cnemidorhiza) sp., from New Britain

I have seen a dozen specimens of this species brought back by the Noona Dan Expedition. The description of this species will be appeared in a separate paper. This is a large and robust species very richly decorated with yellow on the head, thorax and metasoma.

\section{The species group of wisselmerenensis}

This is composed of two, small, metallic species from New Guinea; one is western and the other is eastern in distribution. This is easily separable from the variabilis group in having the entire yellow band on the metanotum (in the variabilis group, the metanotal yellow marking is always interrupted in the middle), and the absence of the yellow marking on the propodeal enclosure.

The condition of the important subgeneric characters of this group is as follows: Caudal fimbria not specially dense but with well appressed, coarse, fuscous hairs; pygidial plate well defined on apical portion only; hind tibia thick, dorso-basal face coarsely sculptured (but not very distinctly so) except for extreme base only; apical tuft of dark hairs on hind femur not distinct.

Further characters of importance of this group are as follows: Head and thorax metallic blue with five stripes on head, mark(s) on labrum, band on pro. 
notum, four stripes on mesoscutum, axilla, lateral broad stripe on mesoscutum, transverse band on metanotum, tubercle, and three transverse marks on side of thorax below wing bases yellow; legs red with yellow markings; metasoma variable in color, either all dark metallic or red basally; mesoscutum and scutellum very densely and minutely punctate, punctures on the latter hardly coarser than those on the former; mesepisternum with upper and median portions a little less strongly punctate than in mesoscutum, lower portion in front of precoxal carina only slightly roughened and not coarsely sculptured; propodeal enclosure large, largely dorsal except apex only; metepisternum slightly roughened with very close and minute punctures; 2nd tergum with punctures becoming sparser to the middle; 3rd tergum with punctures nearly obsolete but with an indication of minute, very dense punctures. Males with further yellow markings on scape and mandible; flagellum not specially long, 3rd segment not longer than two basal segments taken together; exposed sterna not modified, without special fringe of hairs.

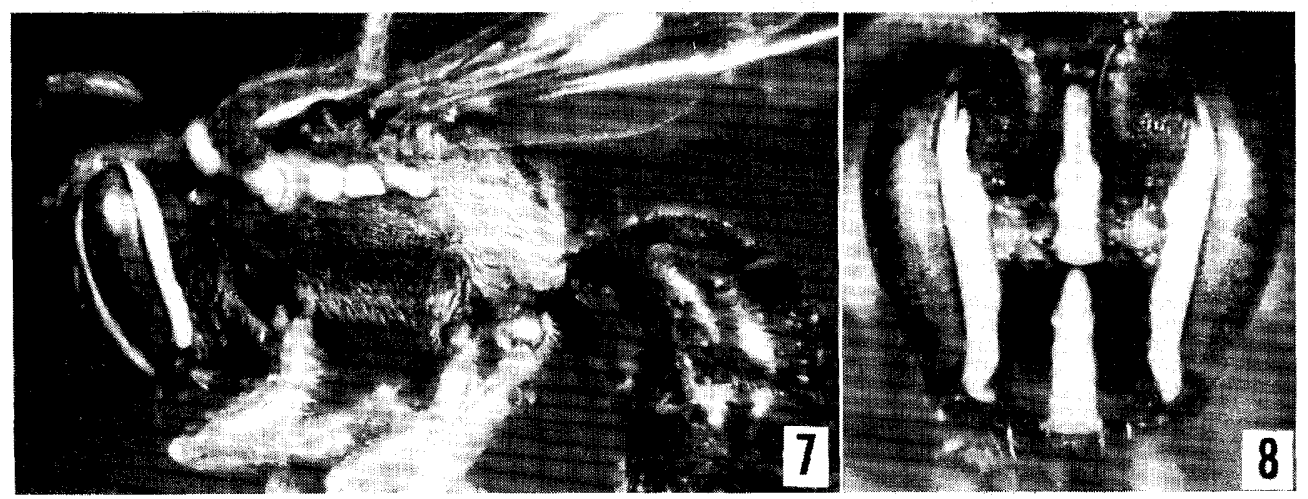

Figs. 7. and 8. Palaeorhiza (Cnemidorhiza) wisselmerenensis Hirashima, female. 7: Lateral view. 8: Frontal view of the head.

(6) Palaeorhiza (Cnemidorhiza) wisselmerenensis Hirashima

Palaeorhiza wisselmerenensis Hirashima, 1975, J. Fac. Agr., Kyushu Univ., 20: 43, female and male. New Guinea (Wisselmeren).

Additional descriptions of characters of this species are as follows : Median yellow stripe of face with upper end separated from mid ocellus ; metepisternum more or less roughened with minute and very close punctures; punctures on 3rd tergum nearly obsolete in female; ratio of width of posterior ocellus to post ocellar distance to ocellocular distance to ocelloccipital distance as $5.5: 7: 12: 11$ in female.

SPECIMENS eXAMINED: 1 female and 1 male, Wisselmeren, Enarotadi, 1900 m, 2-12. VIII. 1962 (J. Sedolacek, by Malaise trap), in Bishop Museum.

Distribution: North-western New Guinea (Wisselmeren). 
Type DePository: Rijksmuseum van Natuurlijke Historie, Leiden.

\section{(7) Palaeorhiza (Cnemidorhiza) parvula, new species}

The description of this new species is based on 4 female and 7 male specimens from Owen Stanley Range, Papua New Guinea. This is very close to wisselmerenensis, but is separated as follows:

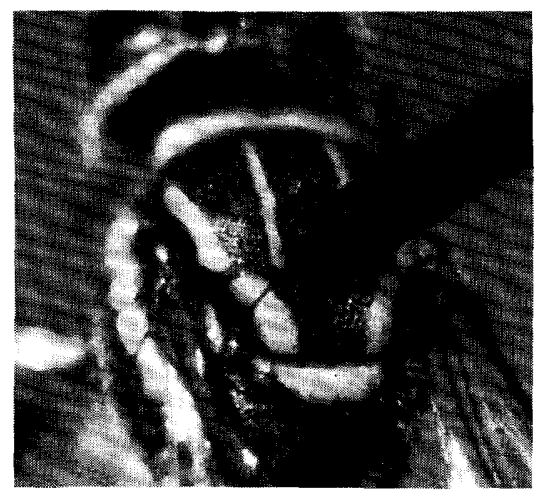

Fig. 9. Palaeorhiza (Cnemidorhiza) parvula, new species. Dorsal view of the female thorax showing the yellow markings.

Two basal terga red, but sometimes 2nd tergum variously darkened apically; in one male specimen, 2nd tergum nearly all dark (purple and blue) ; venter of metasoma more broadly reddened than dorsal portion of metasoma; lower portion of metepisternum slightly smoother; 2nd tergum more densely punctate, but punctures not dense; 3rd tergum with an indication of minute and very dense punctures more distinct.

Type material : Holotype female (BISHOP 12310) and 6 males, Owen Stanly Range, Coilala: Borne, 1950 m, 8-15. III. 1958 (W. W. Brandt) ; 3 paratopotype females and 1 paratopotype male, 24. II.-7. III. 1958 (W. W. Brandt).

Distribution : Papua New Guinea.

Type Depository: B. P. Bishop Museum, Honolulu.

\section{The species group of elegantissima}

This species group is composed of at least four, medium-sized, robust, green species from New Guinea and Australia. The head and thorax are rather well decorated with yellow. This group is very striking in having the 2nd tergum, the extreme latero-apical corner of which is distinctly angulate, nearly right-angled or more acute, and this portion is densely punctate (or nearly coarsely sculptured), although the punctures are considerably smaller than those on the lateral portion of the same tergum. The corresponding portions of the 1st and 3rd terga are also similarly roughened.

The condition of the important subgeneric characters of this group is as 
follows: Caudal fimbria not specially well developed, but with well appressed, coarse, fuscous hairs; pygidial plate not carinate laterally, but apical portion well indicated as smooth area which is not covered with caudal fimbria; hind tibia with dorso-basal face broadened and well marked, very coarsely sculptured in the Australian species, coarsely sculptured or punctate in the New Guinean species ; apical tuft of short fuscous hairs on hind femur conspicuous.

Further characters of importance of this group are as follows: Malar space not more than one-half of basal width of mandible in female ; supraclypeal area with swelling on upper portion gently reducing its height toward above, upper limit indistinct (except kraussi only) ; mesoscutum usually very densely, strongly punctate ; mesepisternum variable in structure (see below); metepisternum rather coarsely sculptured with very small and close punctures and weak wrinkles; 2nd tergum with apical margin produced apically in the middle; two basal terga distinctly punctate ; 3rd tergum more coarsely punctate, although punctures shallow, usually dense. Male: Malar space about as long as that of female or a little longer; face flattened; scape with or without yellow stripe ; flagellum rather long, with 3rd segment longer than broad but not longer than two basal segments together; exposed metasomal sterna without special modification and without special fringe of hairs.

This group is further divided into three species subgroups as follows:

(A) The species subgroup of elegantissima: Two species, elegantissima (Dalla Torre) and pembertoni, new species, from New Guinea. Mesoscutum with lateral yellow stripe or at least with small yellow mark on transscutal suture; scutellum with lateral yellow mark; metanotum with median yellow mark; tibiae of all legs with yellow basal marks in female; punctures on scutellum much coarser than those on mesoscutum; mesepisternum with lower portion coarsely sculptured (or strongly punctate), precoxal carina $\perp$-shaped.

(B) The species subgroup of kraussi: One new species from New Guinea. This is known by the male only. Like the preceding, but lower portion of mesepisternum not specially coarsely sculptured and precoxal carina simply transverse as in the parallela subgroup; supraclypeal area with upper portion distinctly elevated and rather sharply defined; mesoscutum not strongly punctate; 2nd tergum with extreme latero-apical portion much more smoothly sculptured than in the elegantissima and parallela subgroups, with sparser punctures.

(C) The species subgroup of parallela: One species, parallela, with its allied species, if any, from Australia. Mesoscutum without yellow marking except for unusual small mark on transscutal suture; scutellum nearly all yellow (except rejecta and recessiva) ; metanotum also broadly yellow (except recessiva) ; female hind tibia usually without yellow marking; scutellum with punctures much sparser and usually much weaker than those on mesoscutum; mesepisternum 
with lower portion coarsely sculptured, precoxal carina transverse, not Ishaped.

\section{(A) The species SUbGroup of elegantissima}

(8) Palaeorhiza (Cnemidorhiza) elegantissima (Dalla Torre)

Prosopis elegans Smith, 1864, J. Proc. Linnean Soc., London, Bot. and Zool., 8: 91, female. New Guinea.

Prosopis elegantissima Dalla Torre, 1896, Cat. Hym., 10: 22 (new name for Preosopis elegans Smith, 1864, nec Smith, 1853).

Palaeorhiza elegantissima: Michener, 1965, Bull. Amer. Mus. Nat. Hist., 130: 146.

This is a distinct and beautiful species from New Guinea, which is still known by the female only. I have seen the type female of this species at the University Museum, Oxford in 1967.

Female (type) : Length about $8 \mathrm{~mm}$, forewing length, about $6 \mathrm{~mm}$.

Strongly metallic; head and thorax green, metasoma dark green ; clypeus principally purple ; two basal terga with strong purple tint especially on median portions; head with five, rather broad yellow stripes; the median one of face separated from mid ocellus ; thorax with yellow markings as follows: band on pronotum, lateral stripe of mesoscutum, mark on axilla, lateral stripe of scutellum (not reaching apical margin), median mark on metanotum, spot on tegula, apical mark on tubercle, and rather large mark on pre-episternum behind tubercle ; basal halves (or less) of all tibiae pale yellow; femora and tibiae (except for fore femora) fulvous or red; coxae, trochanters and tarsi brownish. Hind tibia with dorso-basal portion broadened, not specially coarsely sculptured, although strongly punctate; this sculpture weakest in the subgenus; pygidial area similar to parallela, an Australian species; apical tuft of black hairs on hind femur distinct. Second segment of fore tarsus about as long and large as 3rd segment; malar space narrower than distance between clypeus and eye; clypeus and supraclypeal area like disrupta, which, however, belongs to another subgenus ; punctures on mesoscutum strong and exceedingly close, those on scutellum stronger than those on mesoscutum; metanotum also with rather strong punctures, those on median portion weakened, those on lateral portion as strong as those on lateral portion of scutellum and still stronger than those on mesoscutum, punctures on median portion of mesepisternum about as coarse and strong as those on mesoscutum or a little coarser and stronger. Apical margins of three basal terga with more or less distinct fringes of short white hairs laterally.

SPecimen examined: The type female only.

Distribution : New Guinea.

TyPe DePository: University Museum, Oxford. 


\section{(9) Palaeorhiza (Cnemidorhiza) pembertoni, new species}

The description of this new species is based on 2 female and 1 male specimens from Papua New Guinea. This is a close relative of elegantissima, but differs from the latter as follows:

Mesoscutum with lateral yellow stripe much reduced to a small mark on transscutal suture (in the type female) or short stripe behind tegula (in the paratype female) ; lateral stripe on scutellum also much reduced to laterobasal spot (close to axilla) ; clypeus dark with green tint, with much less purple reflection; metasoma with fewer purple tint ; legs blackish (or piceous), not fulvous or red; punctures on metanotum weaker than those on mesoscutum; punctures on median portion of mesepisternum weaker than those on mesoscutum.

Female : Slightly less than $9 \mathrm{~mm}$ (the type).

Relative head measurements : length, about 34; width, about 37.5; upper interocular distance, about 19; width of face, 23; lower interocular distance, about 18; eye length, about 27 ; length of clypeus, 13 (about $8+5$ ). Upper portion of supraclypeal area not highly elevated, only slightly dilated laterally, gently reducing its height toward above; frons densely, rather strongly rugoso-punctate ; ocelli more or less large ; lateral ocelli rather widely separated from each other; ratio of posterior ocellar width to postocellar distance to ocellocular distance to ocelloccipital distance as $6.5: 11: 11.5: 14$; area behind ocelli strongly slanting; malar space slightly less than half of basal width of mandible; median portion of clypeus, especially on apical portion, slightly depressed; clypeus and supraclypeal area well convex, its outline arched as seen in profile. Mesoscutum strongly, very densely, nearly rugoso-punctate ; scutellum more strongly punctate than in mesoscutum, punctures sparser; punctures

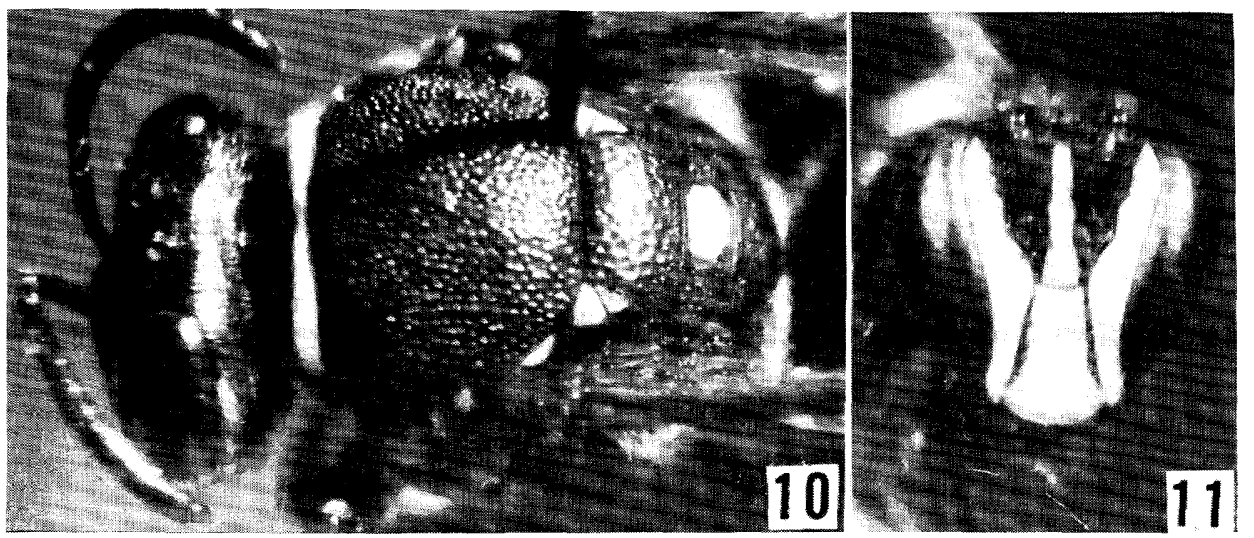

Figs. 10 and 11. Palaeorhiza (Cnemidorhiza) pembertoni, new species. 9: Dorsal view of the female head and thorax, 10: Frontal view of the male head. 
on metanotum considerably weaker than those on mesoscutum; propodeal enclosure well convex, largely dorsal, microscopically shagreened, very weakly shining. First tergum with medio-basal portion more convex than in parallela, nearly smooth, well shining, weakly punctate but punctures somewhat dense; 2nd tergum more broadly convex medially and more constricted basally than in parallela, with apical margin distinctly produced apically in middle; 2nd tergum with apical margin very narrowly impunctate medially (this impunctate margin narrower than in parallela); 3rd tergum much more coarsely punctate than in 2nd (this is more pronounced than in parallela), with broad impunctate apical margin well marked, minutely shagreened.

Head and thorax strongly metallic, green, rather shining; mandible and malar space piceous; clypeus not specially metallic; round mark on labrum, five rather broad stripes on head, band on pronotum, slender mark on transscutal suture of mesoscutum, triangular mark on axilla, small mark on scutellum close to axilla, round mark on median portion of metanotum, spot on tegula, apical mark of tubercle, and mark on upper portion of pre-episternum below tegula lemon yellow; the median stripe of face separated from mid ocellus, but very close to it in the holoype, broadly separated in the paratype. Legs piceous with slight metallic (purple) reflection; basal marks of all tibiae pale yellow. Wings slightly darkened; veins and stigma fuscous. Me tasoma blue-green with distinct purple shade in the type, dark green with slight purple shade in the paratype.

Hairs not conspicuous, short; hairs on vertex and mesoscutum brownish; side of propodeum and metepisternum with covering of short, dense, grey hairs rather distinct, more distinct than in parallela; 1st tergum with sparse fringe of white hairs laterally ; similar tergal hair fringe on 2nd; these fringelike hairs slightly more distinct than in parallela; hairs on apical portion of metasoma blackish.

Male: Slightly smaller than female.

Relative head measurements : length, 31; width, 32.5; upper interocular distance, about 17; width of face, 19.5 ; lower interocular distance, about 12 ; eye length, about 25; length of clypeus, about 12 . Inner margins of eyes strongly converging below as in parallela; malar space about half as long as basal width of mandible, a little shorter than in parallela; clypeus broadly nearly flat ; supraclypeal area similar to female and to parallela; frons strongly, densely rugoso-punctate, more strongly punctate than in parallela; antennae similar to parallela (scape moderate, flagellum elongate with two basal segments much broder than long). Mesoscutum strongly, very densely, nearly rugosely punctate ; punctures on mesoscutum much stronger than in parallela; scutellum well convex, slightly more strongly punctate than in mesoscutum, also considerably more strongly punctate than in parallela; metanotum with punctures 
weak and sparse on median portion; punctures on side of thorax much weaker than those on mesoscutum. Metasomal terga distinctly punctate; extreme latero-apical corner of 2nd tergum distinctly produced and angled like female (more angled than in parallela); this portion also coarsely sculptured (or nearly punctate) as in female, with white fringe of hairs more or less distinct; 7th tergum with latero-apical corner only slightly produced. Hairs similar to female but vertex and mesoscutum almost without brownish hairs.

TyPe MATERIAL : Holotype female (BISHOP 12311) and 1 paratopotype male, Brown River, 5 m, 23. X. 1960 (J. L. Gressitt) ; 1 female, Koitaki, 1500 ft., New Guinea, Nov. - Dec. 1928 (Pemberton Coll.).

Distribution : Papua New Guinea.

Type Depository: B. P. Bishop Museum, Honolulu.

This species is named in honor of the late Mr. C. E. Pemberton who was a famous entomologist in Hawaii.

(B) The species subgroup of kraussi

(10) Palaeorhiza (Cnemidorhiza) kraussi, new species

Unfortunately this species is described by the type male only, The male of this species is superficially similar to that of pembertoni, but is separable, in addition to the subgroup characters mentioned above, by the following diagnosis: body more green with much less purple tint; face less broadly yellow (for details see below description) ; head, thorax and metasoma weakly punctate (very strongly punctate in pembertoni) ; 2nd tergum with impunctate smooth apical margin broader; basal terga without fringe of white hairs (tergal hair fringes more or less distinct in pembertoni) ; 3rd and following terga with more black hairs ; and wings distinctly dusky (nearly subhyaline in pembertoni).

Male : Length about $7.5 \mathrm{~mm}$.

Relative head measurements : length, about 31; width, about 32 ; upper interocular distance, about 17.5; width of face, 20; lower interocular distance, about 12.6; eye length, 24.5 ; length of clypeus, 12.5 (about 7.5 : 5). Inner margins of eyes strongly converging below; mandible weakly bidentate ; malar space distinct but much shorter than basal width of mandible (very slightly longer than in pembertoni) ; clypeus broadly nearly flat or upper portion slightly concave (best seen in profile) ; supraclypeal area with upper portion strongly elevating (more distinctly elevating than in pembertoni and parallela), distinctly dilated laterally, sharply defined from frons; frons flat, densely nearly rugosely punctate, punctures small (frons more weakly punctate than in parallala and much more weakly so than in pembertoni) ; impunctate smooth space lateral ocellus large; ocelli moderate in size ; antennae with proportion of each segments similar to that of pembertoni and parallela. Thorax well convex, broader than head as seen from above ; mesoscutum densely punctate in nearly smooth 


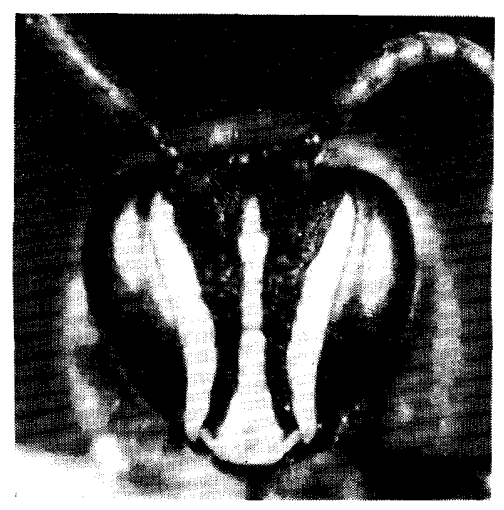

Fig. 12. Palaeorhiza (Cnemidorhiza)

kraussi, new species, male head.

and shining ground, punctures weaker than in parallela and much weaker than in pembertoni; scutellum well convex, slightly more strongly punctate than in mesoscutum, punctures sparser and more irregular in distribution; metanoturn weakly punctate ; propodeal enclosure largely dorsal, microscopically finely shagreened, thus slightly smoother and more shining than in pembertoni pro. podeum outside enclosure densely punctate, punctures distinctly weaker than in parallela and pembertoni ; median portions of pre- and meso-episterna with punctures about as large as those on mesoscutum but sparser; mesepisternum with precoxal carina weaker than in pembertoni. Legs more or less stout; terminal segments of tarsi, especially those of hind pair, large with strong claws as in parallela and pembertoni. Metasoma subcylindrical as in parallela and pembertoni, well convex dorsally; punctures much weaker than in parallela and pembertoni; 2nd tergum well constricted basally, with impunctate smooth apical margin well marked and broader than in pembertoni; apical margin of 2 nd tergum produced apically in middle as in pembertoni; extreme latero-apical corner of 2nd tergum almost right-angled, about as acute as in parallela but less angled than in pembertoni; this portion much more weakly sculptured than in pembertoni.

Head, thorax and metasoma strongly metallic green, shining, but metasoma darker apically; head and thorax with following marks yellow: median mark on labrum, three long stripes on face (the median one broadened on lower portion of clypeus), slender and not specially long stripe on genal area along eye margin, band on pronotum, latero-posterior mark on mesoscutum (close to tegula), triangular mark on axilla, small latero-basal mark on scutellum close to axilla, round mark on median portion of metanotum, spot on tegula, mark on tubercle, and mark on pre-episternum below tegula; scape without yellow stripe; posterior face of propodeum green, only narrowly purple below (largely purple or red-purple in pembertoni and parallela); legs black (or nearly piceous) with strong purple (especially on basal portions) and slight green tints ; basal mark on hind tibia, anterior faces of fore and mid tibiae, and anterior 
stripe on fore tarsus yellow; wings distinctly darkened (nearly subhyaline in parallela and pembertoni) with deep fuscous hairs.

Head and thorax not hairy, with hairs mostly white ; hairs on vertex long, brown; mesoscutum with brownish hairs intermixed; hairs on side of propodeum short, white, but not much sparser than in pembertoni; two basal terga with white hairs very sparse on latero-apical portions, not fringe-like; 3rd and following terga with hairs black; venter of metasoma with hairs brownish basally, fuscous apically, not dense.

Type material: Holotype male (BISHOP 12312), Simbai, 1600-1800 m, NE New Guinea, X. 1968 (N. L. H. Krauss).

Distribution : Papua New Guinea.

Type Depository: B. P, Bishop Museum, Honolulu.

This is named in honor of Mr. N. L. H. Krauss.

\section{(C) The sPecies Subgroup of parallela}

This species subgroup is composed of parallela and its allied species, if any, all are known from Australia. The parallela-complex has been poorly studied. The following 7 forms seem to be included in this complex: parallela, parallela var. recessiva, regina, regina var. humeralis, regalis, disrupta var. rejecta, and parallela var. optima. Cockerell (1929) already synonymized regina, regina var. humeralis and regalis with parallela. I have examined the type of Palaeorhiza disrupta var. rejecta Cockerell, which is kept in the American Museum of Natural History (AMNH, New York), and found that it does not relate to disrupta but is very close to parallela. I have also seen the types of other varieties. Eventually I was impressed that parallela is a polymorphic species but recessiva and rejecta might be treated as good species when the males of them were disclosed.

\section{(11) Palaeorhiza (Cnemidorhiza) parallela Cockerell}

Prosopis parallela Cockerell, 1905, Ann. Mag. Nat. Hist., (7) 16: 400, female. Australia. Palaeorhiza parallela: Michener, 1 965, Bull. A.mer. Mus. Nat. Hist., 130: 146.

This species has been confused with Palaeorhiza disrupta even by Cockerell, as stated above. The subgeneric position of disrupta is apart from parallela according to my system.

Female: Length less than $9 \mathrm{~mm}$.

Strongly metallic; head and thorax green, metasoma darker green, with slight to strong purple tint; ground coloration rarely purple and blue-green (in optima); head with five broad yellow stripes, the median one on face with upper end usually separated from mid ocellus, but rarely very close to it; band on pronotum, mark on axilla (rarely absent), scutellum except basal portion 
(portion next to mesoscutum), metanotum (except extreme lateral portion), mark on tegula, apical mark on tubercle, and mark on pre-episternum behind tubercle yellow; yellow mark on pre-episternum rarely reduced to a sm all spot; mesoscutum rarely with yellow mark on transscutal suture; legs piceous with metallic (usually purple) tint; fore and middle tibiae with yellow marks basally; hind tibia rarely with small yellow spot basally.

Malar space about half as long as basal width of mandible, a little shorter than clypeo-ocular distance ; clypeus and supraclypeal area well convex, its outline slightly arched as seen in profile; upper portion of supraclypeal area not highly elevated, only slightly dilated laterally, gently reducing its height toward above; frons flat, densely rugoso-punctate ; ocelli moderate in size, posterior ocelli well separated each other; area behind ocelli well slanting posteriorly. Mesoscutum strongly and very densely punctate; scutellum smooth, shining, sparsely punctate, punctures irregular in distribution, not stronger than those on mesoscutum; colored portion of metanotum sparsely, more weakly punctate than in scutellum; propodeal enclosure well convex, largely dorsal except apical portion which is subvertical; surface of propodeal enclosure microscopically shagreened (a little smoother than in pembertoni), weakly shining; propodeum outside enclosure very densely, more or less strongly punctate. Fore tarsus with polliniferous hairs well developed; fore tarsus with 1st segment slightly shorter than next 4 segments together except claw (about $12: 14$ ), 2nd segment a little longer than broad, a little larger than 3rd which is larger than 4th. Metasoma compact, well convex; 2nd and 3rd terga largely exposed; extreme latero-apical corner of 2nd tergum nearly rightangled and this portion densely nearly punctate or punctate-roughened; corresponding portions of 1 st and 3rd terga also pun\&ate-roughened; apical impunctate margin of 2 nd tergum not sharply defined, slightly broader than in pembertoni.

Hairs mostly short, white, not conspicuous; hairs on vertex and mesoscuturn slightly brownish; tergal hair fringe absent but white hairs on lateroapical portions of three basal terga more or less dense, slightly fringe-like; hairs on apical portion of metasoma blackish.

Male: Smaller than female.

Similar to female except sexual differences ; posterior portion of thorax and metasoma often more purple, and head and legs with more extensive pale markings (head with round mark on labrum, basal stripe on mandible, clypeus, supraclypeal area, paraocular area except upper portion, anterior stripe of scape, and slender long stripe on genal area along eye margin pale yellow; legs with anterior faces of tibiae and basitarsi of fore and middle pairs and antero-basal mark of hind tibia pale yellow) ; metasoma subcylindrical, with three basal terga large, well convex, more strongly punctate than in female; punctures on two basal terga about as strong as in pembertoni; 7 th tergum with 

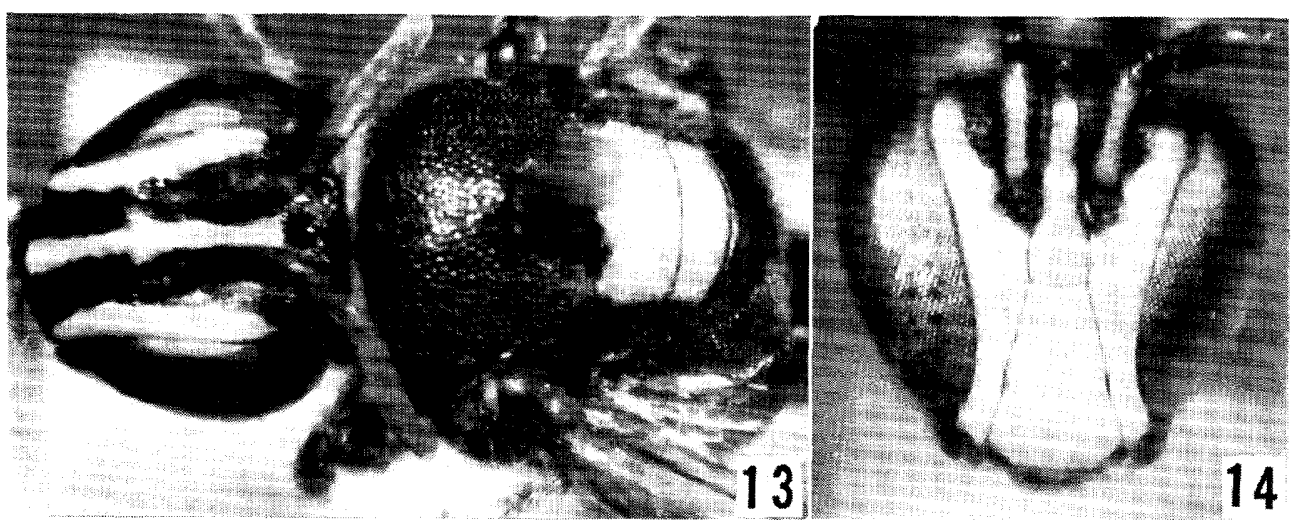

Figs. 13 and 14. Palaeorhiza (Cnemidorhiza) parallela (Cockerell). 12: Dorsal view of the female head and thorax. 13: Frontal view of the male head.

latero-apical projection small, spine-like ; fuscous hairs on 5th and 6th sterna more or less long and dense, slightly more conspicuous than in pembertoni and kraussi.

Distribution : Australia.

Type Depository: British Museum (Nat. Hist.), London.

The color pattern of the parallela-complex varies as follows:

parallela: Yellow markings of head, thorax and legs as stated above ; mesoscutum rarely irregularly marked with purple; metasoma sometimes with red-purple tint on basal terga.

Specimens examined : 2 females (the types of regina) and 1 male (the type of regalis) in $\mathrm{AMNH}$, New York ; 3 females and 1 male, Mackay, in CSIRO, Canberra; 1 male, Mackay, 1910 (Turner Coll.) in University of Kansas (UK, Lawrence) ; 1 female, Cooktown, in Rijksmuseum van Natuurlijke Historie, Leiden; 1 male, Mackay, in Smithsonian Institution, Washington, D. C. ; 2 females, Kuranda (Dodd) and 1 female, Mackay, in Queensland Museum (QM, Brisbane).

humeralis : Pre-episternum without yellow marking behind tubercle ; axilla with or rarely without yellow marking like parallela; transscutal suture of mesoscutum and female hind tibia without yellow marking; metasoma usually with purple tint in male.

Specimens examined : 1 male (regalis) in AMNH, New York; 1 female and 3 males, Mackay, in CSIRO; 1 female, Mackay, 1910 (R. E. Turner), in UK, Lawrence; 1 female, Calsundra, 20. I. 1916, 1 male, Kuranda (Dodd), and 2 males, Mackay, in QM, Brisbane.

optima : Like humeralis (axilla with yellow spot), but with a pair of minute yellow spot on clypeus latero-subapically, and differs in ground coloration as follows: Genal area and metasoma primarily purple with slight blue tint; frons 
and vertex purple and blue; mesoscutum blue-green with purple tint; propodeum and sides of thorax purple and blue-green.

Specimen examined: 1 female (the type) in AMNH, New York.

rejecta: Unlike the precedings, scutellum with a pair of yellow marks; in this respect, this is similar to disrupta, which is not a consubgeneric species as mentioned before, or the elegantissima subgroup of New Guinea; yellow mark on pre-episternum large ; transscutal suture and axilla largely yellow; hind tibia with minute yellow spot at base; metasoma purple and blue-green.

Specimen examined: 1 female (the type) in AMNH, New York.

recessiva: Pre-episternum, transscutal suture, axilla and scutellum without yellow marking; mark on metanotum reduced to a median spot; ground coloration like parallela.

Specimens examined: 1 female, Palm Is., 20. XII.-6. I. 1930-31, in CSIRO, Canberra: 1 female, Palm Is., 30. V. 1926, in QM, Brisbane.

\section{The species group of patricia}

This species group is composed of three, medium-sized to large, strongly metallic blue and shining species from New Guinea. A new species, speciosa, is known by one sex (male) only. The head and thorax are variably decorated with pale markings, which are rather extensive in speciosa.

The condition of the important subgeneric characters of this group are as follows: Caudal fimbria well developed with coarse, well appressed, fuscous hairs; pygidial plate rather large, distinctly carinate laterally; hind tibia thick, dorso-basal face broadened, well marked, very coarsely sculptured except for extreme base only; apical tuft of dark hairs on hind femur distinct.

Further characters of importance of this group are as follows: Metasoma often partly reddened; not hairy, hairs primarily white; tergal hair fringe present or absent; mandible nearly simple or bidentate; malar space at least one half as long as basal width of mandible; swelling of upper supraclypeal area variable ; propodeal enclosure large, usually well convex, largely dorsal except apical portion only on posterior face of propodeum ; punctation of mesoscutum variable ; mesepisternum variable in structure ; metepisternum with very small and very close punctures, not roughened; metasomal terga with punctures variable. Male: See below descriptions of characters for subgroups.

This group is further divided into three distinct species subgroups as follows :

(A) The species subgroup of Patricia: One polymorphic species. Mandible nearly simple at apex; collar of pronotum narrow; mesoscutum strongly and very densely punctate ; scutellum more strongly punctate, broadly nearly flat; mesepisternum with lower portion very coarsely sculptured, transverse precoxal carina strong; two basal terga more or less well punctate ; 3rd tergum with 
punctures nearly obsolete; five narrow stripes on head, narrow band on pronotum, two narrow stripes on mesoscutum, mark on axilla, lateral stripe of mesoscutum, a pair of small lateral marks on metanotum, spot on tubercle, and three small marks on side of thorax below wing bases yellow or ivory; in addition, rarely a pair of small evanescent yellow marks on propodeal enclosure; covering of short white hairs on side of propodeum and metepisternum distinct, dense; lateral hair fringes present on three basal terga. Male: Mandible simple ; face rather broad for the male of Palaeorhiza, with inner eye margins only slightly converging below; scape rather elongate; flagellum long, with 1st segment small and about as long as broad, 2nd broader than long, 3rd much longer than broad and a little shorter than 1st and 2nd combined; at least 3rd and 4th sterna with transverse, glabrous, low elevations ; subapical margins of 4 th and 5th sterna each with a long fringe of delicately curved, fuscous hairs.

(B) The species subgroup of cyanea: One new species. Upper swelling of supraclypeal area distinct, dilated laterally, sharply defined from frons ; collar of pronotum thick, rather flat dorsally; mesoscutum more or less sparsely punctate ; scutellum well convex, sparsely punctate ; metanotum broad, nearly flat, nearly impunctate ; lower portion of mesepisternum in front of precoxal carina not coarsely sculptured; apical margin of 1st tergum more or less distinctly constricted; two basal terga somewhat well punctate; 3rd tergum with punctures not obsolete, larger than those on 2nd; five rather broad stripes on head, interrupted band on pronotum, and a spot on pre-episternum below tegula pale bluish yellow; tergal hair fringe absent ; metasomal terga variably reddened apically. Male: Inner eye margins distinctly converging below; upper swelling of supraclypeal area narrow but slightly more highly elevating than in female; scape short, more or less dilated; flagellum long, two basal segments broader than long, 3rd segment much longer than broad, subequal to two basal segments combined; exposed sterna not modified, strongly punctate, without special fringe of hairs.

(C) The species subgroup of speciosa: One new species. Unlike the preceding, head and thorax rather richly decorated with yellow, as follows: basal stripe of mandible, labrum, clypeus except lateral margin, broad stripe on supraclypeal area which extends above as frontal stripe, broad and long stripe on paraocular area, anterior stripe of scape, band on pronotum, four stripes on mesoscutum, axilla, broad lateral stripe on scutellum, a pair of large transverse marks on metanotum, tubercle, three transverse marks on side of thorax below wing bases, and evanescent small mark on mesepisternum near end of pre-episternal suture ; legs also broadly decorated with yellow; inner eye margins distinctly converging below ; scape short, slightly dilated; flagellum long, two basal segments broader than long, 3rd much longer than broad, 
subequal to two basal segments combined; punctures on mesoscutum weak, not dense ; lower portion of mesepisternum in front of transverse precoxal carina, which is not strong, not coarsely sculptured, with snow-white soft hairs not specially dense; two basal terga very weakly and very sparsely punctate; 3rd tergum with punctures obsolete but with an indication of sparse, shallow, roughened punctures ; sparse white tergal hair fringes present; exposed sterna not modified, not strongly punctate, and without special fringe of hairs.

\section{(A) The species subgroup of Patricia}

\section{(12) Palaeorhiza (Cnemidorhiza) patricia Cheesman}

Palaeorhiza patricia Cheesman, 1948, Ann. Mag. Nat. Hist., (12) 1: 319, female and male. New Guinea.

Palaeorhiza Patricia: Michener, 1965, Bull. Amer. Mus. Nat. Hist., 130: 146.

This is one of the difficult species of Palaeorhiza. Although I have seen the type series of this species at British Museum, the following description is based on the specimens ( 1 female and 3 males) which were collected by me in 1969 at Baiyer River.

Female : Length about $8.5 \mathrm{~mm}$.

Relative head measurements : length, 35.5 ; width, 37 ; upper interocular distance, 18.5; width of face, 23; lower interocular distance, about 19; eye length, 28; length of clypeus, 15.5 (length of clypeus below the line tangential to lower margins of eyes, about 6). Inner margins of eyes slightly converging below; malar space about half as broad as basal width of mandible, broadened posteriorly; clypeus and supraclypeal area well convex, its outline arcuate as seen in profile; median portion of clypeus slightly depressed on apical portion ; upper swelling of supraclypeal area not highly elevating, gently reducing its height toward above, with a narrow deep median sulcus extending to mid ocellus as a frontal line; ocelli rather large, rather close together; ratio of posterior ocellar width to postocellar distance to ocellocular distance to ocelloccipital distance as $7.5: 8.5: 11: 14$; area behind ocelli distinctly slanting, weakly roughened ; clypeus weakly, sparsely, longitudinally striate-punctate, supraclypeal area with median portion impunctate, lateral portion minutely and obscurely punctate ; lower part of frons just above antenna1 socket microscopically shagreened, somewhat broadly impunctate; punctures on frons not strong, not specially dense; postocellar space punctate near mid ocellus and impunctate behind; impunctate and shining space lateral to lateral ocellus broad. Mesoscutum well convex, very densely, strongly and nearly rugosely punctate; scutellum broadly nearly flat, also very densely and rugosely punctate, punctures stronger than those on mesoscutum (except for those on 
median portion of scutellum smaller) ; metanotum weakly convex, microscopically shagreened, therefore less shining than scutellum, punctures on median portion minute, dense, those on lateral portion sparser and larger, but considerably smaller than those on scutellum; medio-basal portion of propodeal enclosure slightly depressed ; surface of enclosure nearly smooth (or microscopically finely lineolate), shining; dorsal face of propodeum outside enclosure densely punctate, punctures closer but slightly smaller than those on lateral portion of metanotum; median portions of pre- and meso-episterna densely and not strongly punctate, punctures about as large and close as those on dorso- lateral face of propodeum, much weaker than those on mesoscutum; metepisternum not roughened, 'with small, dense punctures well noticeable. Wing with stigma rather large ; 2nd submarginal cell slightly longer than twothirds of 1st along lower margin (about 11.5 : 16). Fore tarsus with polliniferous hairs well developed, slightly more elongate than in the elegantissima group, 2nd segment slightly longer than broad, longer than 3rd which is about as long as broad and larger than next segment. First tergum moderately large, well convex, apical margin weakly but broadly depressed; 2nd tergum well convex transversely, narrowly and deeply constricted basally, broadly constricted apically; 1st tergum with weak, somewhat dense punctures which are about as large as those on median portion of metanotum; apical margin of 1st tergum rather broadly impunctate; 2nd tergum slightly more strongly punctate than in lst, with broad impunctate apical margin well marked; extreme lateroapical portions of 2 nd tergum punctate-roughened (similar to the elegantissima group) ; 3rd tergum with punctures not well marked, much weaker than those on 2 nd.

Head and thorax distinctly metallic, steel blue, shining, except for malar space, clypeus, lower portion of supraclypeal area and lower portion of genal area piceous; face with three ivory stripes slender, the median one broadly separated from mid ocellus ; genal area with ivory stripe along eye margin also slender, shorter than those on face; thorax with following markings also ivory: narrow band on pronotum nearly interrupted in middle, a pair of slender, not specially long stripes on mesoscutum, triangular mark on axilla, narrow, short, lateral stripe on scutellum, evanescent lateral mark on metanotum, small mark on tubercle, and three transverse marks on side of thorax below wing bases; tegula brown with slight metallic (mostly purple) shade; posterior face of propodeum broadly red-purple below; legs piceous with metallic shades of purple and blue, also with small antero-basal yellow mark on fore tibia; metasoma darker blue, two basal terga broadly piceous or more reddened medially, with distinct purple tint.

Hairs primarily white, not hairy; hairs on vertex and mesoscutum brownish; lower portion of metepisternum and side of propodeum with covering of 

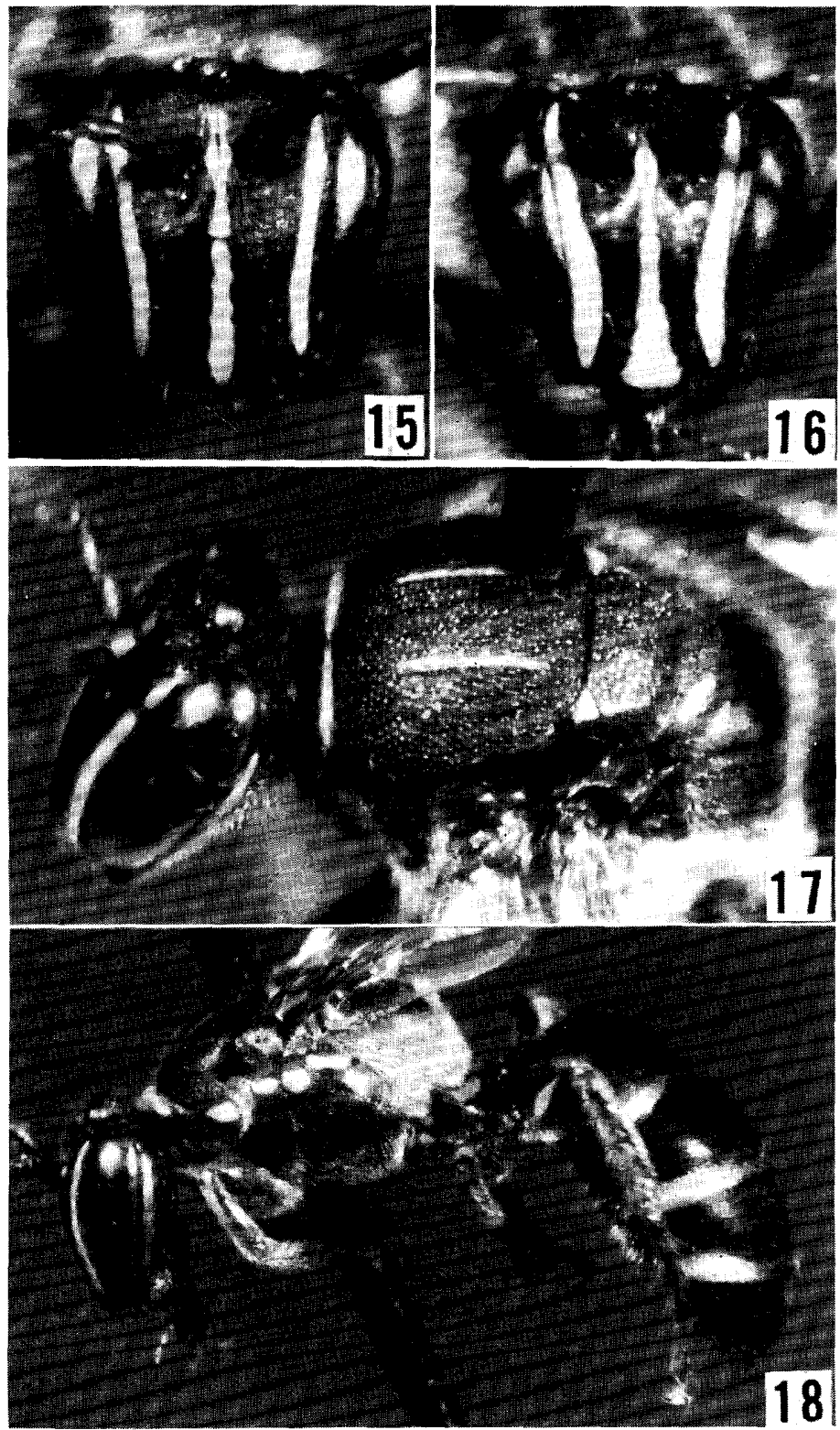

Figs. 15-18. Palaeorhiza (Cnemidorhiza) Patricia Cheesman. 15 : Female head. 16: Male head. 17: Dorsal view of the female head and thorax. 18: Lateral view of t he male.

dense, short, white hairs distinct; posterior face of propodeum with longer, subappressed white hairs also distinct; hairs on apical portion of metasoma, including caudal fimbria, nearly black; three basal terga with distinct lateral fringes of short white dense hairs. 
VARIATION: The holotype female is provided with the tergal fringes of hairs sparse and not distinct. A female specimen from Finisterre Range, Papua New Guinea, delicately differs from the Baiyer River specimen as follows: thorax darker blue with slight green shade on mesoscutum and scutellum and green shade stronger on side of propodeum; markings on head and thorax yellow ; mesoscutum and scutellum slightly more strongly punctate ; and pre- and meso-episterna distinctly more strongly punctate, punctures more irregular in size. A female specimen from Karimui, Papua New Guinea, also differs from the above description as follows: propodeal enclosure with a pair of evanescent small yellow spots; hind femur with yellow stripe on dorsal face; punctures on head and metasoma weaker and sparser; impunctate apical margins of three basal terga broader (especially the one on 2nd tergum) ; and punctures on side of thorax strong.

Male: Slightly slenderer than female.

Relative head measurements : length, 37; width, 38; upper interocular distance, about 18; width of face, 22; lower interocular distance, 17.5; eye length, 30 ; clypeal length, 17 (length of clypeus below the line tangential to lower margins of eyes, about 6). Malar space and clypeo-ocular distance much elongate than in female ; the former slightly shorter than basal width of mandible; face below antennae nearly smooth, shining, with very weak and sparse punctures; punctures on frons about as strong and dense as in female. Scutellum a little more convex than in female; punctures on thorax a little weaker than in female except for those on propodeum not noticeably smaller; lower portion of mesepisternum coarsely sculptured but less strongly so than in female, precoxal carina slightly stronger than in female. Hind tibia more or less thick with dorso-basal face rather coarsely sculptured except for extreme base only. Metasoma rather broad, only slightly slenderer and longer than in female; constriction of broad apical margin of 2nd tergum distinct; 7th tergum with lateroapical projection triangular, broadly separated each other; apical margin of 2 nd sternum well produced apically in middle; 2 nd to 5 th sterna with transverse glabrous elevations variable, broad and very distinct on 3rd and 4th sterna in one specimen, moderate in one specimen and weak and not conspicuous in another; apical impunctate margins of 2nd to 5th sterna well marked, very broad on 2nd, broad on 3rd, and narrowed on following sterna; these margins nearly hyaline.

Ground coloration similar to female; three ivory stripes on face slightly broader than in female, but the median one enlarged on apical portion of clypeus ; transverse mark on labrum ivory; scape without pale marking; pale marking on thorax very variable, as shown below; legs with anterior stripes (or marks) on all femora and basal marks of variable size on all tibiae pale yellow; anterior faces of tibiae and femora of fore and middle pairs pale 
fulvous in variable extent.

White hairs on thorax, especially those on propodeum, and tergal fringes of white hairs on three basal terga distinct as in female.

VARIATION OF MARKING: Pale marking of thorax similar to female in one specimen ; in one specimen, a pair of slender marks present on propodeal enclosure in addition to usual pale markings described for female ; in one specimen, pale marking much reduced (stripes on mesoscutum almost disappearing and scutellum and metanotum without pale marking) but propodeal enclosure with a pair of small evanescent pale markings.

Specimens examined: 1 female and 3 males, Baiyer River, $1100 \mathrm{~m}$, Papua New Guinea, 1-5. IX. 1969 (Y. Hirashima) ; 1 female, Finisterre Range, Saidor: Kiambavi, 22-29. VII. 1958 (W. W. Brandt) ; 1 female, Karimui, Papua New Guinea, 4. VI. 1961 (J. L. Gressitt) ; all in Bishop Museum.

Distribution : Papua New Guinea.

Type Depository : British Museum (Nat. Hist.), London.

(B) The SPECIES SUbGRoup of cyanea

(13) Palaeorhiza (Cnemidorhiza) cyanea, new species

This is also a beautiful blue species. The description of this new species is based on 2 female and 4 male specimens from Papua New Guinea. This is easily separable from Patricia as follows : supraclypeal area more highly convex, dilated laterally, upper end abruptly and more sharply separated from frons; pronotum thick, flattened dorsally; mesoscutum and scutellum much more sparsely punctate; metanotum broad and nearly flat, nearly impunctate; lower portion of mesepisternum not coarsely sculptured; 2nd tergum more convex in middle, not constricted basally and apically; 3rd tergum with stronger punctures; and mandible bidentate in both sexes. The mode of the pale marking of the thorax of this species is also much different from that of Patricia as stated before.

Female: Length about $9.5 \mathrm{~mm}$.

Relative head measurements : length, 36; width, 38; upper interocular distance, about 20.5; width of face, 24.5 ; lower interocular distance, 19; eye length, about 27; clypeal length, about 15 (length of clypeus below the line tangential to lower margins of eyes, about 6). Inner eye margins more converging below than in Patricia; upper portion of head, especially area behind ocelli, more strongly punctate than in Patricia. Mesoscutum with punctures somewhat irregular in size and distribution, more or less strong, more or less dense ; scutellum slightly convex, rather sparsely, more or less weakly punctate, punctures sparser and a little weaker than those on median portion of mesoscutum; dorso-lateral face of propodeum outside enclosure distinctly 
punctate, punctures closer and slightly stronger than those on pre- and mesepisterna; metepisternum not roughened but with very close, small punctures well noticeable. Apical portion of 1st tergum well constricted (much more pronounced than in Patricia) ; punctures on 3rd tergum sparse, distinct, stronger than those on 2nd.

Head and thorax steel blue, shining, with slight purple tint on propodeum, and with slight green shade on frons; malar space, clypeus and supraclypeal area blackened; head with five, broad, long, pale yellow stripes; the median one distinctly interrupted on upper margin of clypeus, narrow on front, and broadly separated from mid ocellus; pronotum with interrupted band on collar also pale yellow; no further pale marking on thorax except for a spot on side of thorax below tegula in the specimen from Keglsugl; legs with distinct metallic (mostly blue) shade; fore tibia fulvous in front basally and with small pale (bluish) spots near base. Wings subhyaline basally, darkened apically. Metasoma darker blue with purple shade, apical portions of terga reddened or red-subhyaline in various extent,

Head and thorax with hairs white; no brown hairs on vertex and mesoscutum; covering hairs on side of propodeum and metepisternum slightly sparser than in Patricia, less conspicuous; metasoma with hairs white basally, black apically.

Male: Slightly smaller and slenderer than female.

Relative head measurements : length, 36.5; width, 38; upper interocular distance, 20.5; width of face, 23; lower interocular distace, 15 ; eye length, 28.5 ; clypeal length, 15.5 (clypeal length below the line tangential to lower margins of eyes, about 6). Similar to female except as follows: Inner eye margins strongly converging below; malar space slightly longer than in female, shorter than basal width of mandible; clypeo-ocular distance about as long as in female; clypeus largely flat, depressed on upper portion, median portion longitudinally lineolate, nearly impunctate ; upper swelling of supraclypeal area narrow, upper end more highly elevating than in female; glabrous space between eye and lateral ocellus more conspicuous; area behind ocelli subhorizontal; ratio of lateral ocellar width to interocellar distance to oce1locular distance to ocelloccipital distance as $7: 9: 14: 14$, hind tibia thick (but slightly narrower than in female) with dorso-basal face somewhat roughened; 2nd tergum more convex in middle; 7th tergum with triangular projection latero-apically; glabrous apical margin rather broad in middle of 2nd sternum, narrow on 3rd and nearly obsolete on 4th and 5th.

Frons without yellow stripe between supraclypeal area and mid ocellus; scape without yellow stripe; labrum with median pale mark; median stripe of clypeus broader than in female; metasoma much more purple than in female; fore and middle legs with more yellow markings on tibiae than in female; 
otherwise ground coloration and pale marking similar to female. Fuscous hairs on 4th to 6th sterna dense, not forming special fringe.

Color variAtion: In one male specimen, a small pale spot present on tubercle; in one male specimen, evanescent small pale marks on transscutal suture of mesoscutum, axilla, tubercle, and upper portion of pre-episternum in addition to band on pronotum.

Type materiad: Holotype female (BISHOP 12313) and 2 males, Keglsugl, 2700 m, Mt. Wilhelm, Chimbu, Papua New Guinea, 11-12. VIII. 1969 (Y. Hirashima); 1 female and 1 male, Mt. Giluwe, $2500 \mathrm{~m}$, Papua New Guinea, 7. VI. 1963 (M. Sedlacek) ; 1 male, Daulo Pass, 2500 m, Papua New Guinea, 2. V. 1959 (C. D. Michener).

Distribution: Papua New Guinea.

TYPE depository: B. P. Bishop Museum, Honolulu.

(C) The Species subgroup of speciosa

\section{(14) Palaeorhiza (Cnemidorhiza) speciosa, new species}

Unfortunately this species is known by the type male only. This is also a beautiful blue species and unlike the two preceding species, the head and thorax are rather richly decorated with yellow. The metasoma of the male of this species is primarily purple as in cyanea.

M ale : Length about $7.5 \mathrm{~mm}$, more or less slender, with long wings as usual.

Relative head measurements : length, 29; width, 30.5 ; upper interocular distance, 16; width of face, 19; lower interocular distance, 12 ; eye length, 23 ; length of clypeus, a little over 12 (length of clypeus below a line tangential to lower margins of eyes, about 4.5). Mandible bidentate, with long and large lower tooth; malar space well developed but much shorter than basal width of mandible, subequal to clypeo-ocular distance; clypeus hardly convex, broadly flat above; swelling of supraclypeal area not dilated laterally, rather abruptly reducing its height toward above, upper limit not differentiated from frons ; lower portion of supraclypeal area broadly flat like upper portion of clypeus; ocelli more or less large ; ratio of width of posterior ocellus to postocellar distance to ocellocular distance to ocelloccipital distance as 6.5:8:10: 11. Clypeus and lower portion of supraclypeal area microscopically lineolate (or nearly reticulate), not specially shining; paraocular area smoother and more shining; frons well punctate, but punctures small. Collar of pronotum thick, narrowed medially as seen from above; scutellum well convex (similar to cyanea), with punctures sparser but stronger than those on mesoscutum; metanotum much lower than scutellum, almost flat, nearly smooth, with sparse, minute punctures ; propodeal enclosure large, almost all dorsal, mediobasal portion indistinctly concave ; surface of enclosure strongly shining, 
microscopically lineolate except for glabrous median portion.

Head and thorax strongly metallic, steel blue, shining, with slight purple shade on posterior part of thorax; head and thorax with pale yellow markings as described before; frontal stripe not reaching mid ocellus; flagellum reddened beneath; legs piceous with metallic (purple and blue) shades, with large pale yellow markings on femora and tibiae of all legs and tarsi of fore and middle legs ; metasoma with strong purple shade on piceous ground; 1st tergum with distinct, 2nd with slight blue or blue-green tints; apical margins of exposed terga broadly pale ferruginous subhyaline. Wings subhyaline with distal portions darkened; veins and stigma brown.

Rather hairy ; head and thorax with more or less dense, rather long, white hairs; vertex almost without brownish hairs ; densely branched white hairs on propodeum longer than in cyanea, much longer than in patricia; 1st tergum with more or less distinct lateral fringes of white hairs on apical margin; similar white fringes of longer hairs on 2nd and 3rd; fringe of 3rd sparse.

type material : Holotype male (BISHOP 12314), Upper Chimbu Valley, 2200 m, Papua New Guinea, 5. VII. 1955 (J. L. Gressitt).

Distribution: Papua New Guinea.

Type depository: B. P. Bishop Museum, Honolulu.

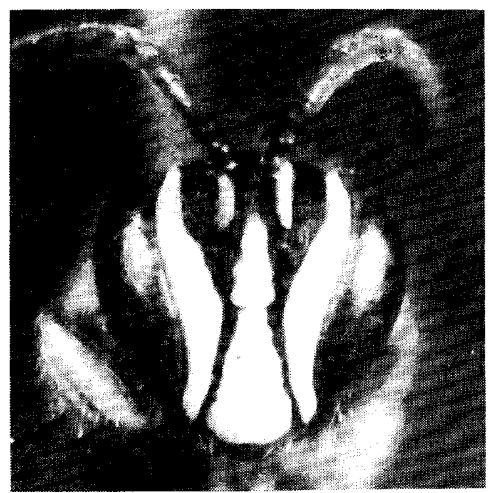

Fig 19. Palaeorhiza (Cnemidorhiza) speciosa new species. Male head.

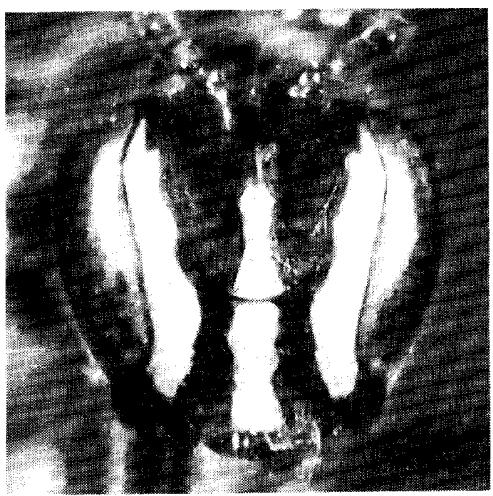

Fig. 20. Palaeorhiza (Cnemidorhiza) nasalis, new species. Female head.

\section{The species group of nasalis}

This species group is composed of but one, rather large, strongly metallic blue species from New Guinea, the male of which is not known, unfortunately. This is superficially very similar to the cyanea subgroup of the patricicia group, but is readily distinguished by the remarkable characters of the head. The head is thick, especially on the lower portion, the clypeus is strongly reflected and 
elevated on the apical portion and the mandible provided with a triangular process in the middle of the inner margin. These unusual characters of the head may deserve a subgeneric rank, but it is included in the subgenus Cnemidorhiza until the male of clypealis is discovered.

The condition of the important subgeneric characters of this group is as follows : Caudal fimbria well developed, composed of long, coarse, fuscous hairs; pygidial plate poor, not distinctly carinate laterally, apical portion of the plate only slightly marked; hind tibia thick, dorso-basal face broad, well marked, very coarsely sculptured except for extreme base only; apical tuft of short dense brown hairs distinct.

Further characters of importance of this group are as follows: Head and thorax strongly metallic, shining blue, with pale yellow markings primarily confined to head and pronotum only; thorax not densely, not strongly punctate; punctures on scutellum hardly coarser than those on mesoscutum ; metanotum broad, flat, nearly impunctate ; propodeal enclosure rather large, rather well convex, slanting but almost all dorsal; metepisternum with lower portion not coarsely sculptured, but punctures slightly roughened, precoxal carina transverse, not specially strong, punctures on upper and median portions slightly weaker than those on mesoscutum; metepisternum with very close and very small punctures, but surface not roughened; apical margin of 1st tergum slightly constricted; 2nd tergum broadly and distinctly convex ; metasomal terga weakly punctate; punctures on 3rd tergum not distinct but slightly more roughened than those on 2nd, sparse; hairs mostly white (even on legs) except black hairs on apical portion of metasoma.

\section{(15) Palaeorhiza (Cnemidorhiza) nasalis, new species}

Female: About as large as Patricia.

In addition to the characters mentioned above, the female of this new species is distinct as follows:

Relative head measurements : length, 35; width, 38; upper interocular distance, about 22; width of face, about 25.5 ; lower interocular distance, about 19.5; eye length, 27; length of clypeus, 13 (lower portion of clypeus beyond lower margins of eyes, about 6.5). Lower portion of head rather broad as seen in front and rather thick as seen in profile; inner margins of eyes slightly converging below; mandible robust with triangular process in middle of inner margin as stated before (unfortunately, the mandibles of the type female broken and lost after the above description was made) ; malar space distinct, about half as long as basal width of mandible; clypeo-ocular distance long, slightly longer than malar space; about upper half of clypeus flat; swelling of supraclypeal area distinct, dilated laterally, upper portion well elevated, rather sharply defined from frons; ocelli more or less small; ratio 
of width of postocellus to postocellar distance to ocellocular distance to ocelloccipital distance as $8: 8: 15: 16$; space just in front of mid ocellus concave, smooth and impunctate; this glabrous space rather broad and well marked; space lateral to postocellus broadly glabrous.

Wings slightly dusky, distal margins more darkened; stigma and veins brown; the former moderate in size; the latter rather large.

Head and thorax distinctly metallic, steel blue, shining, with slight purple tint in some light; purple shade distinct on genal area and posterior face of propodeum; clypeus and supraclypeal area delicate in color, dark with slight brassy and blue-green shades ; five broad stripes on head and interrupted band on pronotum pale yellow with very slight bluish tint; the median stripe on face interrupted on upper margin of clypeus and narrowed on frons, upper end broadly separated from mid ocellus; the lateral stripe on face triangularly pointed on top; small evanescent spot on transscutal suture of mesoscutum, also evanescent spot on tubercle and also small evanescent spots on side of thorax below wing bases pale yellow. Tegula brown with slight metallic shade. Legs piceous with blue and purple tints; short and narrow stripes on anterior face of fore tibia and small spot on base of middle tibia bluish yellow. Metasoma piceous with blue and purple shades; apical margins of four basal terga (and probably apical margin of 5th also) broadly ferruginous subhyaline; venter of metasoma dark.

Vertex and mesoscutum without dark hairs; white covering hairs on metepisternum and side of propodeum rather distinct; tergal hair fringe absent, but sparse white hairs on latero-apical portion more or less fringe-like ; underside of thorax with long, rather dense, somewhat coarse, silvery hairs (this feature suggestive of the presence of more decorative hairs in male).

Type material: Holotype female (BISHOP 12315), Owen Stanley Range, Coilala: Borne, 1950 m, Papua New Guinea, 16-31. III. 1958 (W. W. Brandt).

Distribution: Papua New Guinea.

Type depository: B. P. Bishop Museum, Honolulu.

\section{The species group of viridifrons}

This group is composed of but one, rather large, robust, weakly metallic species from Australia. The male is unknown. The mode of yellow marking of the thorax (no yellow marking on the head) is remarkable, as stated below.

The condition of the important subgeneric characters of this group is as follows: Caudal fimbria with dense, well appressed, coarse, fuscous hairs not specially long; pygidial area well covered with caudalfimbria (presence of pygidial plate not ascertained by me); hind tibia with dorso-basal face coarsely sculptured except for extreme base only; apical tuft of fuscous hairs on hind femur present but not conspicuous. 
Further characters of importance of this group are as follows : Malar space more than basal half of mandible; swelling of supraclypeal area dilated laterally, gently reducing its height toward above and merging into frons, upper limit obscure; lower portion of mesepisternum in front of not strong precoxal carina slightly coarsely sculptured ; mesoscutum very densely punctate, punctures small (in viridifrons, punctures on mesoscutum indistinctly larger than in gratiosa); scutellum sparsely punctate, punctures scarcely coarser than those on mesoscutum; metanotum rather distinctly convex in the middle, sparsely and very weakly punctate; propodeal enclosure well convex, largely dorsal ;

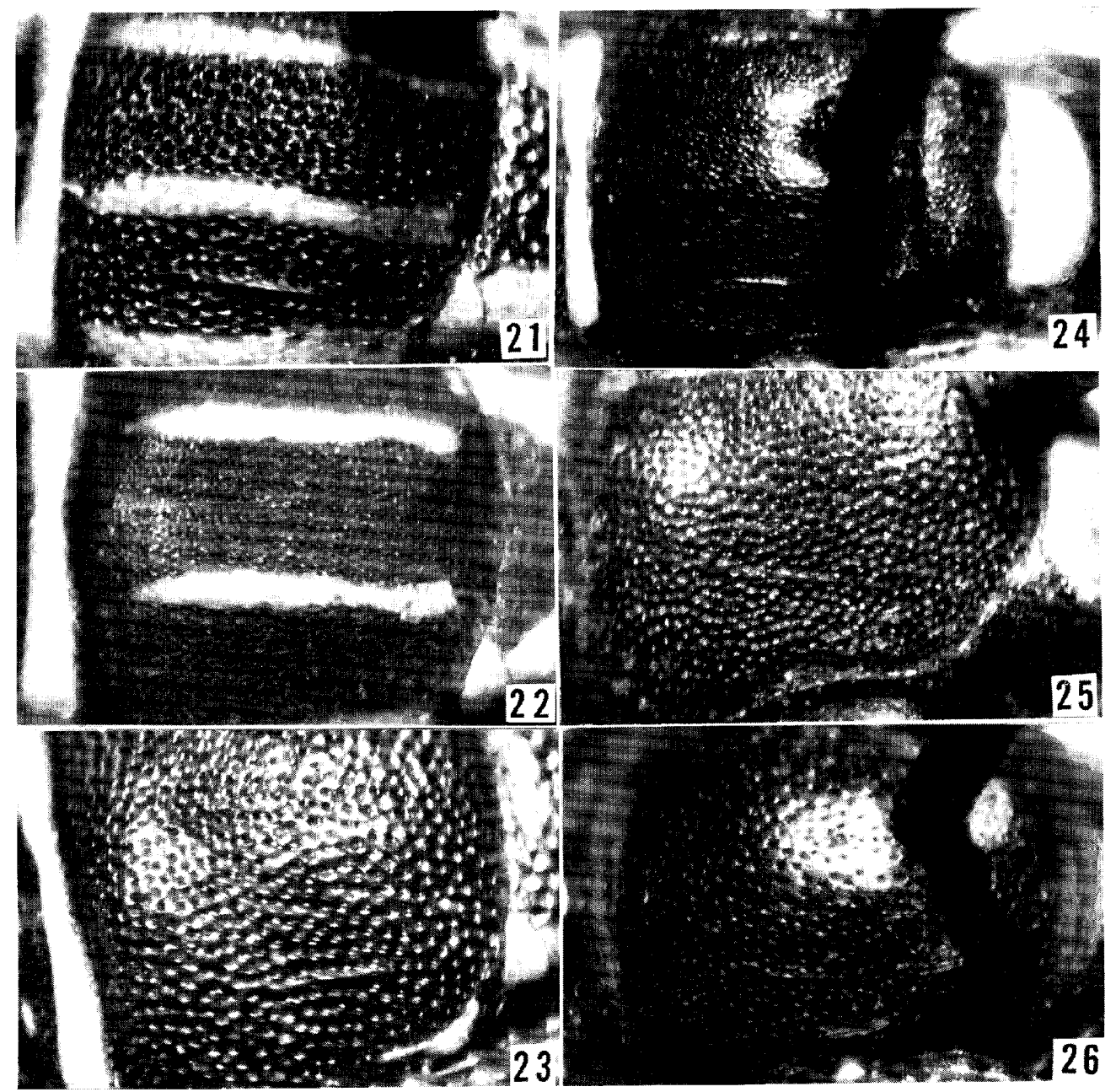

Figs. 21-26. Punctation of the mesoscutum of Palaeorhiza(Cnemidorhiza) spp., females. 21 : simulans, new species. 22: delicata, new species. 23: pembertoni, new species. 24: gratiosa Cheesman. 25 :viridifrons Cockerell. 26: convexa, new species. Note the yellow maculation also. 
metepisternum slightly roughened with an indication of very close and minute punctures; 1st tergum constricted on apical portion ; 2nd tergum well convex in the middle, with apical margin slightly produced apically in the middle; metasoma well punctate; punctation of 2 nd tergum remarkable, as shown below; punctures on 3rd tergum not obsolete, very dense even on median and lateral portions, weaker than those on median portion of 2nd tergum.

\section{(16) Palaeorhiza (Cnemidorhiza) viridifrons Cockerell}

Palaeorhiza viridifrons Cockerell, 1921, Mern. Queensl. Mus., 7: 86, female. Australia.

Palaeorhiza viridifrons: Michener, 1965, Bull. Amer. Mus. Nat. Hist., 130: 146.

I have seen the type female of this species which is preserved in the Queensland Museum and one more female specimen kept in the Smithsonian Institution (Dayboro, 27. I. 1927, H. Hacker). The latter is larger (about 10 $\mathrm{mm}$ ) than the type (about $9 \mathrm{~mm}$ ).

In addition to the characters mentioned above, the female of this species is distinctive as follows :

Head and thorax weakly metallic green, weakly shining; face below antennae and lower portion of genal area nearly piceous; green shade of frons, on which the name of species is based, not specially distinctive ; scutellum, metanotum, apical half of tubercle and upper half of pre-episternum orange yellow ; no other yellow marking on any part of body; legs piceous with slight purple tint; metasoma piceous, with very slight metallic shade on basal terga in some light; wings distinctly brownish subhyaline.

Clypeus not specially convex, antero-median portion slightly depressed ; clypeus longitudinally well striate-punctate; supraclypeal area longitudinally lineolate ; clypeo-ocular distance long, longer than malar space; postocellus more or less large, width of it slightly shorter than postocellar distance (about $8: 10$ ), which is slightly shorter than ocellocular distance (about 12) and about two-thirds as long as ocelloccipital distance ; upper portion of head behind postocelli distinctly slanting behind; punctures on median portion of mesepisternum sparser than but about as large as those on mesoscutum; 2nd tergum with size and density of punctures very variable, i. e., punctures weak and sparse on median portion, distinct and moderately dense on sublateral portion, again weak but very dense on lateral portion, and coarse and sparse on extreme lateral portion; narrow apical impunctate margin of 2nd tergum distinct even on extreme lateral portion.

Distribution: Australia.

Type Depository: Queensland Museum, Brisbane. 


\section{The species group of gratiosa}

This is composed of but one, large, robust, strongly metallic and hairy species from New Guinea. The mode of yellow marking of the head and thorax of this species is remarkable, as described below.

The condition of the important subgeneric characters of this group is as follows : Caudal fimbria dense, composed of black coarse hairs ; pygidial plate distinct with sharp lateral carina; dorso-basal face of hind femur very broad, well marked, coarsely sculptured with strong wrinkles except for extreme base only; apical tuft of short, dense, fuscous hairs of hind femur distinct.

Further characters of importance of this group are as follows: Malar space long but shorter than basal width of mandible; supraclypeal area with upper limit sharply defined from frons; lower portion of mesepisternum in front of strong transverse precoxal carina coarsely sculptured with dense transverse wrinkles and punctures ; mesoscutum with punctures extremely dense, very small; scutellum with median portion slightly depressed, similary punctate as in mesoscutum ; metanotum distinctly convex in midddle ; propodeal enclosure more or less small,. rather short as seen from above, distinctly slanting: metepisternum slightly roughened with an indication of very small and close punctures; 2nd tergum well convex, apical margin slightly produced apically in middle, punctures weak and sparse in middle, dense and distinct on lateral portion; 3rd tergum very densely punctate nearly all over, punctures small, slightly smaller than those on 2nd. Male: mandible bidentate; malar space longer than in female, subequal to basal width of mandible; clypeus not specially flattened ; scape rather long; flagellum long, 1st segment about as long as broad, 2nd broader than long, 3rd a little longer than broad, a little shorter than 4th; hind tibia thick, dorso-basal face broad and slightly coarsely sculptured except for extreme base only; 7th tergum with latero-apical fringe of long curved blackish hairs distinct, latero-apical projection distinct; 3rd to 5th sterna each with a long fringe of delicately curved brown hairs subapically ; at least 4 th and 5 th sterna with transverse glabrous elevations.

\section{(17) Palaeorhiza (Cnemidorhiza) gratiosa Cheesman}

Palaeorhiza gratiosa Cheesman, 1948, Ann. Mag. Nat. Hist., (12) 1 : 320, female. New Guinea. Palaeorhiza gratiosa: Michener, 1965, Bull. Amer. Mus. Nat. Hist., 130: 146.

This species was described by Cheesman based on 3 female specimens taken on Mt. Tafa, $8500 \mathrm{ft}$., Northern Territory, New Guinea, on blossom of wild raspberry. In 1969, I collected this species from 4 other localities, i. e., Mt. Kaindi $(2360 \mathrm{~m})$, Bulldog Road (2600 m), Keglsugle (2700 m, Mt. Wilhelm) and Mt. Guiluwe $(2500 \mathrm{~m})$. Thus, this is one of the typical montane species of Papua New Guinea. Very interestingly, this is a ground nesting species, as stated elsewhere in this paper. 


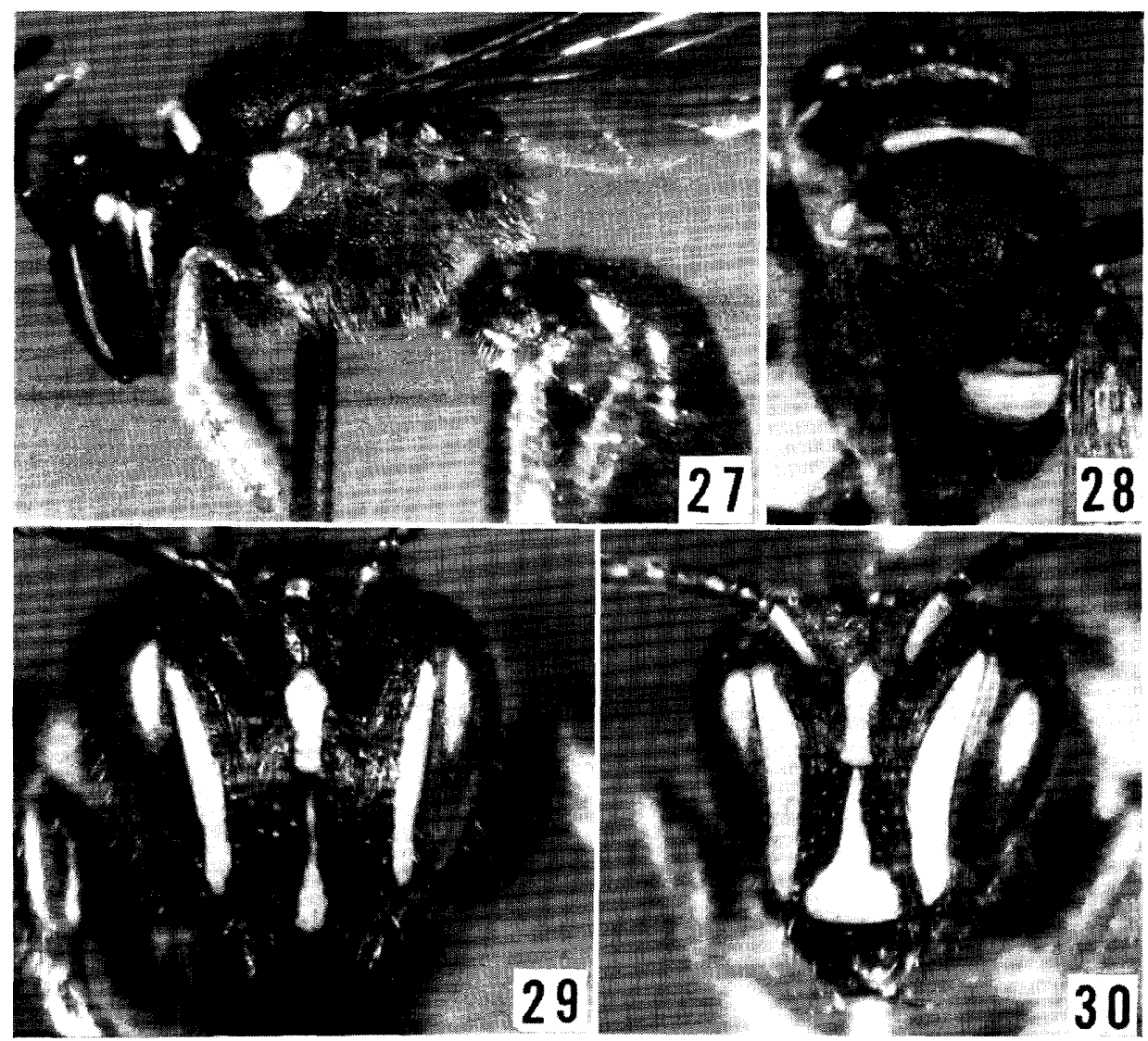

Figs. 27-30. Palaeorhiza (Cnemidorhiea) gratiosa Cheesman. 27: Lateral view of the female. 28: Dorsal view of the female thorax. 29: Female head. 30: Male head.

In addition to the characters mentioned above, this is distinct as follows:

Female : Length $9.5-10.5 \mathrm{~mm}$.

Relative head measurements : length, 38; width, 42 ; width of face, 27.5 ; upper interocular distance, 24; lower interocular distance, 22; length of eye, 29; length of clypeus, 16. Malar space longer than one-half of basal width of mandible; upper half of supraclypeal area dilated laterally, more or less abruptly reducing its height toward above; frons flat, densely rugoso-punctate on microscopically roughened ground; ocelli rather small; ratio of width of postocellus to postocellar distance to ocellocular distance to ocelloccipital distance as $8: 8.5: 17: 15$.

Head and thorax strongly metallic, blue-green, rather shining, with purple tint variable; mandible, labrum, malar space, clypeus, supraclypeal area and lower portion of genal area black or nearly so; five stripes on head, band on pronotum, narrow band on scutellum next to metanotum (rarely absent), 
broad band on metanotum, mark on ferruginous tegula and mark on tubercle orange yellow; the median stripe of face often weakened or sometimes interrupted on upper portion of clypeus; frons without yellow marking between supraclypeal area and mid ocellus ; wings brownish, distinctly dusky; legs black basally, red apically; metasoma darker blue-green with stronger purple shade than in thorax.

Head and thorax hairy; hairs on face, frons, vertex, genal area near eye, mesoscutum and scutellum blackish, those on the rest of thorax brownish; hairs on metanotum yellow; lateral face of propodeum almost without covering of short white hairs; hairs on legs brown basally, reddened on red portions; metasoma with hairs black but hairs on basal terga brown; no tergal hair fringe.

Male (new to science) : Slightly smaller and slenderer than female.

Very similar to female except as follows: malar space longer, subequal to basal width of mandible ; stripes of face broader, and the median one broadened on apical portion of clypeus ; scape yellow in front; precoxal carina on mesepisternum very strong ; 1st tergum large, long, well convex basally; 2nd tergum well convex, but not specially so in the middle, slightly constricted at base; metasomal terga more distinctly punctate than in female.

Spectmens examined: From Mt. Kaindi, $2360 \mathrm{~m}, 1$ male, 22. ViI. 1969, 5 males, 19. VIII. 1969, on Rubus, 1 male and 3 females, 23. VIII. 1969, on Rubus, 1 female, 11-12. IX. 1969, 2 males and 3 females, 24-25. IX. 1969, on Rubus; from Bulldog Road, $2600 \mathrm{~m}, 35 \mathrm{~km}$ SE of Wau, 2 males and 5 females, at nesting site, 25-27. VII. 1969; from Keglsugle (Mt. Wilhelm), 2700 m, 1 male, 4. VIII. 1969; from Mt. Giluwe, Western Highland, 2500 m, 1 male, 28-29. VIII. 1969; all were collected by me.

Distrieution : Papua New Guinea.

Type depository: British Museum (Nat. Hist.), London.

\section{The species group of convexa}

This species group is composed of but one, large, robust, dark metallic species from New Guinea. The male is unknown, unfortunately. This is striking in having no yellow maculation on any part of the body except for a pair of small evanescent pale marks on the upper portion of supraclypeal area.

The condition of the important subgeneric characters of this group are as follows : Caudal fimbria well developed, composed of rather long, dense, coarse, black hairs; pygidial plate rather narrow, well defined with distinct carina laterally; hind tibia thick, dorso-basal face broad, very coarsely sculptured except for extreme base only; apical tuft of short hairs dense, not specially dark in color. 
Further characters of importance of this group are as follows: Clypeus and supraclypeal area unusually strongly convex; frons lateral to frontal line also longitudinally elevated; mesoscutum strongly punctate, punctures not dense on median portion ; scutellum slightly depressed in the middle, elevated on lateral portion ; metanotum distinctly convex in the middle; propodeum rather short, enclosure more or less small, very slanting; metepisternum with lower portion not roughened but with very strong, well separated punctures, precoxal carina strong and transverse, punctures on mesepisternum irregular in size, closer than those on mesoscutum; metepisternum slightly roughened with very close and small punctures; metasoma large with 2nd tergum broadly and strongly convex; 2nd tergum sparsely punctate, but punctures distinct, with apical impunctate margin more or less broad and rather well marked, its extreme lateral portion still glabrous; 3rd tergum densely punctate, punctures weaker than those on 2 nd, those on extreme lateral portion roughened and considerably larger than those on median portion of the same tergum.

\section{(18) Palaeorhiza (Cnemidorhiza) convexa, new species}

Female: Length slightly less than $11 \mathrm{~mm}$; fore wing about $9.5 \mathrm{~mm}$ long.

In addition to the characters mentioned above, this is striking as follows: Relative head measurements : length, about 38 ; width, 42; width of face, 26 ; upper interocular distance, about 22; lower interocular distance, 23 ; eye length, 29; clypeal length, about 16. Lower inner margins of eyes subparallel or only slightly converging below; mandible bidentate with broad apical blade, lower tooth broad; malar space about half as long as basal width of mandible; ocelli rather large, close together, postocellar distance slightly shorter than width of postocellus (about $7: 9$ ) ; upper portion of head behind ocelli distinctly slanting posteriorly. Mesoscutum well convex, strongly punctate on microscopically tessellate ground, punctures on median portion not dense; punctures on scutellum very irregular in size, those on median portion considerably weaker than those on latera Iportion; metanotum microscopically roughened with microscopical, dense punctures on median portion ; propodeal enclosure microscopically lineolate or tessellate, weakly shining. Wings brownish subhyaline, distal margin more darkened; stigma more or less small for the size of wing; 2nd submarginal cell large, broadened on apical portion. Broad apical margin of 1st tergum and median portion of 2nd nearly smooth, distinctly shining.

Head and thorax dark green with irregular purple shade, not distinctly shining; mandible, malar space, clypeus, supraclypeal area, and lower portion of genal area black or nearly so, rather shining; scape shining black; flagellum dull and brown beneath; head with an indication of evanescent pale marking on genal area along eye margin in addition to supraclypeal area; legs 
piceous with slight purple tint; metasoma dark purple with blue-green shade, more shining than in thorax.

Rather hairy; hairs on head and thorax rather dense, long, nearly black except for those on propodeum brownish; covering of brownish gray, very short hairs on metepisternum and lateral face of propodeum not specially distinct; hairs on legs fuscous to brown ; basal terga scanty of hairs ; hairs on apical portion of metasoma nearly black.

Type MATERIAL : Holotype female (BISHOP 12316), Enarotadi, Wisselmeren, 1900 m, N. W. New Guinea, 2212. VIII. 1962 (J. Sedlacek, by Malaise trap).

Distribution : Western New Guinea (Wisselmeren),

Type Depository: B. P. Bishop Museum, Honolulu.

\section{Acknowledgements}

I am grateful to the following institutions and entomologists for the loan of the valuable specimens: American Museum of Natural History, New York (Dr. J. G. Rozen, Jr.) ; Bishop Museum, Honolulu (Dr. J. L. Gressitt) ; CSIRO, Canberra (Dr. E. F. Riek) ; Rijksmuseum van Natuurlijke Historie, Leiden (Dr. M. A. Lieftinck) ; Queensland Museum, Brisbane (Dr. T. Houston) ; Zoologisk Museum, Kopenhagen (Dr. B. Petersen) ; and University of Kansas, Lawrence (Prof. C. D. Michener). 